\title{
Analysis of the Adsorption of Toxic Chromium (VI) by Untreated and Chitosan Treated Banana and Areca Fiber
}

\author{
Hosne Ara Begum1, A. K. M. Monjurul Haque ${ }^{*}$, Md. Didarul Islam², M. Mehedi Hasan'2, \\ Suza Ahmed3', Md. Razzak4, Ruhul Amin Khan4 \\ ${ }^{1}$ Department of Yarn Engineering, Bangladesh University of Textiles, Dhaka, Bangladesh \\ ${ }^{2}$ Department of Applied Science \& Chemical Engineering, University of Dhaka, Dhaka, Bangladesh \\ ${ }^{3}$ Department of Fabric Engineering, Bangladesh University of Textiles, Dhaka, Bangladesh \\ ${ }^{4}$ Institute of Radiation and Polymer Technology, Bangladesh Atomic Energy Commission, Dhaka, Bangladesh \\ Email: ${ }^{\star}$ monjurulhaque01@gmail.com
}

How to cite this paper: Begum, H.A., Haque, A.K.M.M. Islam, Md.D., Hasan, M.M., Ahmed, S., Razzak, Md. and Khan, R.A. (2020) Analysis of the Adsorption of Toxic Chromium (VI) by Untreated and Chitosan Treated Banana and Areca Fiber. Journal of Textile Science and Technology, 6, 81-106.

https://doi.org/10.4236/jtst.2020.62007

Received: February 21, 2020

Accepted: May 3, 2020

Published: May 6, 2020

Copyright $\odot 2020$ by author(s) and Scientific Research Publishing Inc. This work is licensed under the Creative Commons Attribution International License (CC BY 4.0).

http://creativecommons.org/licenses/by/4.0/ (c) (i) Open Access

\begin{abstract}
This paper work involves bunch experiments to investigate the effect of contact time, $\mathrm{pH}$, and adsorbent dose on the extent of adsorption by bio-composites. Adsorption capacity of Chromium (VI) onto chitosan coated with banana and areca fiber was investigated in a batch system by considering the effects of various parameters like contact time, initial concentration, $\mathrm{pH}$ and adsorbent dose. The chitosan and fibers (banana and areca) were then cross-linked with glutaraldehyde to remove chromium [Cr (VI)] from water via static adsorption. It was found that optimum chromium absorption capacity of chitosan was assessed at $\mathrm{pH}$ of 2.5 to 4.5 and contact time of 30 to 180 minutes for raw banana and areca fiber and for chitosan treated banana \& areca fiber. Though optimum adsorption of chromium of chitosan was measured 34.17 ppm (85.42\%) from a $100 \mathrm{ml}$ solution containing 40 parts per million (ppm) of $\mathrm{Cr}(\mathrm{VI})$ at 120 minutes, $\mathrm{pH}$ of 3.0 and 120 milligram (mg) adsorbent dose size, use of composite will be more favorable in the point of environmental concern as well as low cost because chitosan preparation is comparatively costly then banana and areca fiber. On the other hand, untreated banana and areca fiber optimum adsorption of chromium measured $3.65 \mathrm{ppm}(9.1 \%)$ at $180 \mathrm{~min}$ and, $\mathrm{pH}$ of 4.5 and $140 \mathrm{mg}$ adsorbent dose size and $3.76 \mathrm{ppm}(9.4 \%)$ at $180 \mathrm{~min}$, pH of 4.5 and $160 \mathrm{mg}$ adsorbent dose size respectively. In case of chitosan treated banana fiber, it was observed that adsorption was increased from 17.664 to 30.057 (75.14\%). On the other hand, for areca fiber with chitosan, it was observed that adsorption was increased from 21.664 to 30.156 (75.39\%) ppm. The Langmuir and Freundlich adsorption models were used
\end{abstract}


for the mathematical description of the adsorption of chromium ion onto composites and it was found that the Langmuir adsorption isotherm was more fitted models which mean that a monolayer adsorption surface was created. After analyzing from IBM SPSS 25 software, we got the standard deviation value of adsorbed $\mathrm{Cr}$ by raw chitosan, untreated banana and areca of $\mathrm{pH}$ test results were $9.399,1.072,0.728 \mathrm{ppm}$, time test results were 2.163, $0.859,0.896 \mathrm{ppm}$ and adsorbent dose test results were 6.588, 0.966, $1.211 \mathrm{ppm}$ correspondingly. The standard deviation results of $\mathrm{pH}$, time and amount of treated banana fiber test results were 1.831, 2.693 and $5.469 \mathrm{ppm}$ congruently. On the other hand, the standard deviation results of $\mathrm{pH}$, time and amount of treated areca fiber test results were 3.293, 2.673 and $4.152 \mathrm{ppm}$ individually. Fourier transform infrared (FT-IR) spectroscopy analysis indicated that both amino and hydroxyl groups of chitosan, banana and areca fiber were engaged in the adsorption.

\section{Keywords}

Adsorption, Heavy Metal, Chitosan, Banana Fiber, Areca Fiber, Toxicity

\section{Introduction}

Textile and tannery industries are the largest water users in Bangladesh. When discharged as effluent, that water is polluting the rivers and surface water. Department of Environment (DoE) is working to enforce Effluent Treatment Plant (ETP) in the dye houses of the country. Setting up ETP is a prerequisite for having clearance from DoE for factory setting. As per DoE Director General, 52\% of Bangladesh's existing industries have established ETP and other $48 \%$ industries have not. Wastewater from dyeing and finishing processes in the textile manufacturing industry constitutes a substantial birthplace of pollution which exhibits intense color, high chemical oxygen demand, fluctuating $\mathrm{pH}$, heavy metal and suspended particles [1]. Many of those factories are directly discharging to the water body. During each stage of textile industry different types of chemicals are used such as strong acids, strong alkalis, inorganic chlorinated compounds, hypochlorite of sodium, organic compound such as dye stuff, bleaching agent, finishing chemicals, starch, thickening agent, surface active chemicals, wetting and dispensing agents and salts of heavy metals like lead $(\mathrm{Pb})$, chromium $(\mathrm{Cr})$ etc. [2]. On the other side, huge quantities of chemicals and organic solvents such as chromate and bi-chromate salts, aniline, butyl acetate, ethanol, benzene, toluene, sulfuric acid and ammonium hydrogen sulfide are used [3]. Among these chemicals chromium is the most dangerous and harmful metals that directly or indirectly accumulated in our body and are responsible for damaging liver, kidney, nervous system, and irregular heart rhythm. For that reason, it is one of the major concerns for environment scientists to remove these chemicals in such a way so that all of the chemicals can be remove with low price and the 
material (adsorbent) will be biodegradable, so that no residue will remain after adsorption. Environment scientists are now working for removing these chemicals in such a way so that all of the chemicals can be effectively removed with low price and as well as this technique may not be problematic for the environment (forming any residue). Many methods are now available for the removal of chromium from the effluents, some of them are chemical precipitation, ion-exchange, adsorption, bio-adsorption, membrane filtration, electrochemical treatment technologies [4] [5] [6] [7] [8]. Bio-sorption of heavy metals from aqueous solutions is a relatively new process that has been confirmed a very promising process in the removal of heavy metal contaminants. The major advantages of bio-adsorption are its high effectiveness in reducing the heavy metal ions and the use of inexpensive bio-adsorbents [9].

Banana and areca fiber is natural biodegradable fibers with advantages such as high tensile strength, excellent thermal conductivity and also has an excellent metal adsorption capacity [10] [11] [12] [13]. Adsorption is the adhesion of atoms, ions, or molecules from a gas, liquid, or dissolved solid to a surface. Adsorption is now recognized as an effective and economic method for heavy metal wastewater treatment. Agricultural wastes, industrial byproducts and wastes and natural substances have been studied as adsorbents for the heavy metal wastewater treatment [14]. Some of the common low cost adsorbents are raw or modified kaolinite and montmorillonite clay, chemically modified plant wastes, industrial by-products such as lignin, lignite, natural zeolites etc. [15] [16]. Bio-sorption of heavy metals from aqueous solutions is a relatively new process that has been confirmed a very promising process in the removal of heavy metal contaminants. The major advantages of bio-sorption are its high effectiveness in reducing the heavy metal ions and the use of inexpensive bio-sorbents [9]. Bio-sorption processes are particularly suitable to treat dilute heavy metal wastewater. Typical bio sorbents can be derived from three sources as follows: 1) Non-living biomass such as bark, lignin, shrimp, krill, squid, and crab shell, etc.; 2) Algal biomass; 3) Microbial biomass, e.g. bacteria, fungi and yeast. Different forms of inexpensive, non-living plant material such as potato peels, sawdust, eggshell, seed shells etc., have been widely investigated as potential bio-sorbents for heavy metals. The adsorption process offers flexibility in design and operation and in many cases will produce high-quality treated effluent. In addition, because adsorption is sometimes reversible, adsorbents can be regenerated by suitable desorption process [5]. Now today, Banana fiber and areca shells are directly exposed into the environment and they have no use at all. Though due to the exposure of these may not create any problem for the environment but both of them can be used as adsorbent and can be used in ETP plant with or without modification. So in this study, banana and areca are treated with chitosan (bio-composites) are used to removal of chromium from waste water and investigate and compare these data to scrutinize the best optimization point and best composition of bio-composite for adsorption of heavy 
metal from waste water.

\section{Literature Review}

The textile and clothing industries provide the single source of growth in Bangladesh's rapidly developing economy [17]. The tannery is one of the oldest industries of the world. Now a day the demand of leather and leather goods in the global market is about 120 million US dollars [18]. By 2002 exports of textiles, clothing, and ready-made garments (RMG) accounted for 77\% of Bangladesh's total merchandise exports [17]. As of 2016 Bangladesh held the 2nd place in producing garments just after China. Bangladesh is the world's second-largest apparel exporter of western (fast) fashion brands. Sixty percent of the export contracts of western brands are with European buyers and about forty percent with American buyers [19]. In the past few decades, textile and tannery industries play an important role in the economy of Bangladesh. At present, 113 tanneries in Bangladesh among them 60 percent are located in Hazaribagh [20]. Tannery industry has been associated with high pollution due to the bad smell, organic solid waste and toxic water caused during the traditional process of manufacturing [21]. Several studies suggest that nearly $200 \mathrm{~kg}$ of leather is manufactured from 1 ton of raw hides and skins [22] [23]. A report from FAO revealed that approximately 8.5 million tons of solid waste are generated during the production of 11 million raw hides and skins [24]. At present 6.5 million tons of raw hides and skins are processed worldwide [25]. In textile industry, heavy metals particularly, lead $(\mathrm{Pb})$, chromium $(\mathrm{Cr})$, cadmium $(\mathrm{Cd})$ and copper $(\mathrm{Cu})$ are widely used for the production of color pigments of textile dyes [26]. Such heavy metals can exist in naturally in the structures of textile or they can penetrate into fibers of textile during production, dyeing process or through protective agents used during storage. These heavy metals which have transferred to the environment are highly toxic and can bio-accumulate in the human body aquatic life, natural water-bodies and also possibly trapped in the soil [27]. Chromium (III) sulfate dissolves to give the hexaaquachromium (III) cation, $\left[\mathrm{Cr}\left(\mathrm{H}_{2} \mathrm{O}\right)_{6}\right]^{3+}$, which at higher $\mathrm{pH}$ undergoes processes called olation to give polychromium (III) compounds that are active in tanning, being the cross-linking of the collagen subunits [28]. The chemistry of $\left[\mathrm{Cr}\left(\mathrm{H}_{2} \mathrm{O}\right)_{6}\right]^{3+}$ is more complex in the tanning bath rather than in water due to the presence of a variety of ligands. Some ligands include the sulfate anion, the collagen's carboxyl groups, amine groups from the side chains of the amino acids, and masking agents. Masking agents are carboxylic acids, such as acetic acid, used to suppress formation of polychromium (III) chains. Masking agents allow the tanner to further increase the $\mathrm{pH}$ to increase collagen's reactivity without inhibiting the penetration of the chromium (III) complexes. Collagen is characterized by a high content of glycine, proline, and hydroxyproline [29]. These residues give rise to collagen's helical structure. Collagen's high content of hydroxyproline allows for significant cross-linking by hydrogen bonding within the helical structure. Ionized carboxyl 
groups $\left(\mathrm{RCO}_{2}^{-}\right)$are formed by hydrolysis of the collagen by the action of hydroxide. This conversion occurs during the liming process, before introduction of the tanning agent (chromium salts). The ionized carboxyl groups coordinate as ligands to the chromium (III) centers of the oxo-hydroxide clusters. Chromium's ability to form such stable bridged bonds explains why it is considered one of the most efficient tanning compounds [30].

\subsection{Chromium in Human Body}

\subsubsection{Chromium [III] Compounds}

Oral administration of chromic chloride to humans resulted in $99 \%$ of the dose being recovered in faces while about $94 \%$ was recovered after duodenal administration. In both cases, about $0.5 \%$ was excreted in urine indicating poor absorption of $\mathrm{Cr}$ [III] following oral ingestion [31]. After human exposure to $\mathrm{Cr}$ [III] by inhalation, urinary concentrations of chromium were found to be increased indicating respiratory absorption [32] [33]. However, the extent of the pulmonary uptake of $\mathrm{Cr}[\mathrm{III}]$ is influenced by the nature of the compound [34]. After one volunteer had immersed his hand in tanning liquor for $1 \mathrm{~h}$, monitoring of blood and urine failed to detect dermal absorption of chromic sulphate. Studies in experimental animals are compatible with the poor absorption of $\mathrm{Cr}$ [III] salts following exposure by oral, dermal and inhalation routes [35] [36] [37].

\subsubsection{Chromium [VI] Compounds}

Following oral administration of sodium chromate in tracer doses to humans, faecal excretion of chromium indicated that about $10 \%$ of the administered dose had been absorbed from the gastrointestinal tract. After duodenal administration approximately half of the administered radioactivity appeared to have been absorbed on the basis of faecal excretion while $10 \%$ appeared in the urine during the first $24 \mathrm{~h}$. Reduction of $\mathrm{Cr}$ [VI] to the trivalent form was demonstrated [31]. Correlation between respiratory exposure to $\mathrm{Cr}[\mathrm{VI}]$ and urinary excretion of chromium has been demonstrated in welders and in workers in the chrome plating industry [38] [39]. The respiratory uptake rate is unknown, but depends on the solubility of the chromium compound. $\mathrm{Cr}$ [VI] is reduced in the lower respiratory tract by the epithelial lining fluid and by pulmonary alveolar macrophages. At equivalent numbers of cells, the reducing efficiency of alveolar macrophages by biochemical mechanisms was significantly greater in tobacco smokers than in nonsmokers [40].

\subsection{Chromium Adsorption on Chitosan}

Accordingly, when $\mathrm{pH}$ was held in the strongly acidic region, preferably below $\mathrm{pH} 3$, over $90 \%$ removal was attained regardless of initial concentration and adsorbent dose. $\mathrm{Cr}(\mathrm{VI})$ exists predominantly as $\mathrm{HCrO}_{4}^{-}$in aqueous solution below $\mathrm{pH} 4$ [41]. Since the amino groups of chitosan are protonated at this $\mathrm{pH}$, electrostatic interaction occurs between the sorbent and $\mathrm{HCrO}_{4}^{-}$ions resulting in high chromium removal. The extent of removal was suppressed by approx- 
imately $15 \%$ when initial concentration was increased from 15 to $95 \mathrm{mg} / \mathrm{l}$ for constant $\mathrm{pH}$ and adsorbent dose levels. On the contrary, the adsorption capacity of chitosan was calculated to increase from 2.9 to $102 \mathrm{mg} / \mathrm{g}$ with rise in initial concentration from 5 to $100 \mathrm{mg} / \mathrm{l}$. When $\mathrm{pH}$ was held below $\mathrm{pH} 3$, an adsorbent dose of 7 gram/liter (g/l) was sufficient to ensure $>90 \% \mathrm{Cr}(\mathrm{VI})$ removal for solutions up to $55 \mathrm{mg} / \mathrm{l}$ initial concentration. For lower initial concentrations, even $1.8 \mathrm{~g} / \mathrm{l}$ was efficient at significantly acidic $\mathrm{pH}$ [41].

\subsection{Chitosan}

\subsubsection{Structure of Chitin and Chitosan}

Chitin (Figure 1), a homopolymer of 2-acetamido-2-deoxy-D-glucose ( $\mathrm{N}$ acetylglucosamine) residues linked by $\beta$-(1-4) bonds, is a common constituent of insect exoskeletons, shells of crustaceans and fungal cell walls [42]. Chitosan (Figure 1) is a polymer obtained from deacetylation of chitin, is a cationic polysaccharide with linear chain consisting of $\beta$ - $(1,4)$-linked 2 -acetamino-2-deoxy- $\beta$ Dglucopyranose and 2-amino-2-deoxy- $\beta$-D-glucopyranose. There has been a large increase in chitosan research during the past decade. This is due to its biocompability, biodegradability, non-toxicity, and other unique properties such as film forming ability, chelation and adsorption properties and antimicrobial activity. Chitosan is used in dietary supplements, water treatment, food preservation, agriculture, cosmetics, pulp \& paper and medicinal application [43] [44].

\subsubsection{Sources of Chitosan}

Chitosan and its derivatives are examples of value-added materials. They are produced from chitin, which is a natural carbohydrate polymer found in the skeleton of crustaceans, such as crab, shrimp and lobster, as well as in the exoskeleton of marine zooplankton spp., including coral and jellyfishes Insects, such as butterflies and ladybugs, also have chitin in their wings and the cell walls of yeast, mushrooms and other fungi also contain this substance. In Asian countries such as Thailand, Japan, and China, fishery wastes such as shrimp, lobster, and crab shells have been developed into one of the promising options to produce chitosan. These wastes could be obtained for free from local fishery industries (Table 1). Since such wastes are abundantly available, chitosan may be

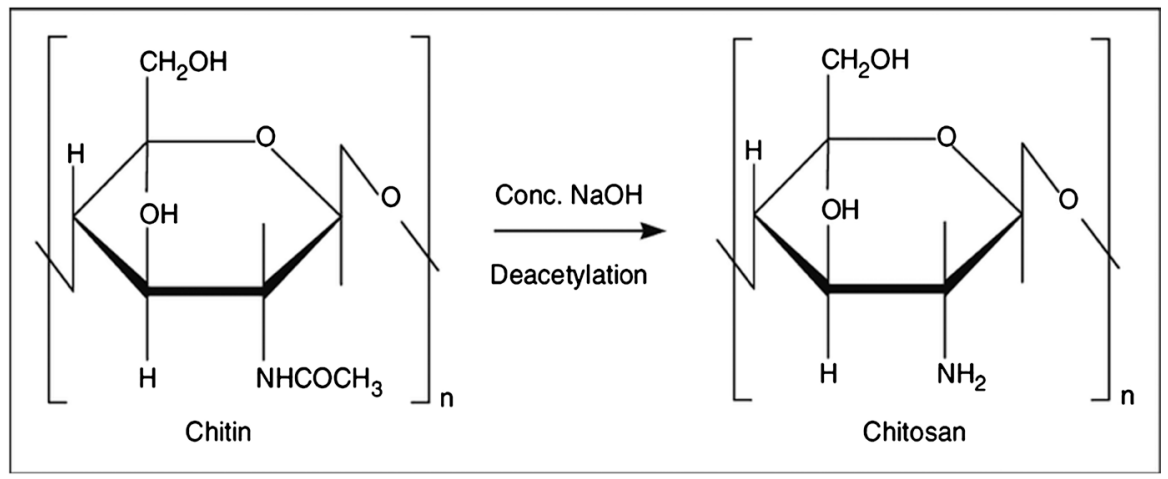

Figure 1. Structure of chitin and chitosan. 
produced at low cost [45] [46].

Bangladesh processes and exports large quantities shrimp every year and the prawn processing plants produce large quantities of shells that remain unused. The shells become waste, although this prawn shell waste (Table 1) is high in natural polymer, thus creating environmental pollution. Extraction of chitosan from prawn shell and its utilization in fields such as agriculture, water purification, pharmaceuticals as excipients, medicinal use, fat reduction, textiles, etc., will add new dimensions in terms of economics [46].

\subsubsection{Physical Properties of Chitosan}

\section{- Degree of Deacetylation (DD)}

The difference between chitin and chitosan lie in the degree of deacetylation (DD), usually defined as the ratio of the amount of glucosamine to the total amount of $\mathrm{N}$-acetylglucosamine and glucosamine, being the most important parameter determined for chitosan and chitin. Degree of deacetylation ranges from ranges from $56 \%$ to $99 \%$, depending on the species and the preparation methods. Generally, chitin with a degree of deacetylation of $70 \%$ or above is known as chitosan. There are some factors affecting the extent of deacetylation such as concentration of alkali, reaction temperature, time of reaction, Particle size and previous treatment of chitin [47]. The principal characteristics of chitosan that may affect its sorption properties are its degree of deacetylation and crystallinity. In Figure 1 shows the degree of deacetylation controls the fraction of free amine groups that will be available for interactions with metal ions. The amine groups on chitosan are much more reactive than the acetamide groups on chitin [48] [49]. The degree of acetylation (DA) and the crystallinity of chitin molecules affect the solubility in common solvents. Figure 2 shows reducing the acetylation level in chitosan ensures the presence of free amino groups, which can be easily protonated in an acid environment, making chitosan water soluble below $\mathrm{pH}$ about 6.5 [50]. In acid conditions, when the amino groups are protonated, chitosan becomes a soluble polycation (Figure 2) [51].

\section{- Viscosity}

Viscosity of Chitosan is affected by many factors, such as the degree of deacetylation,

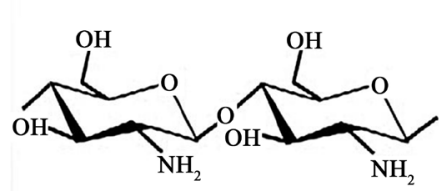

Chitonsan
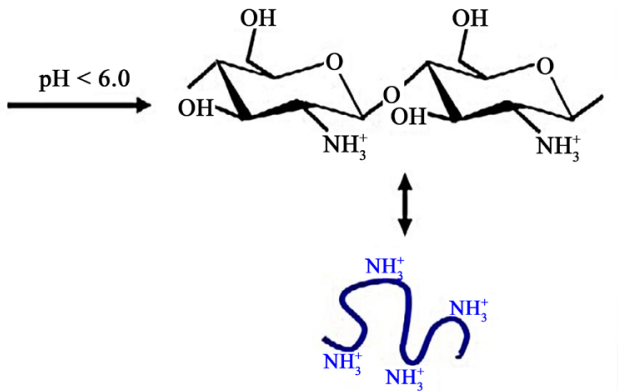

Chitosan as polycationic electrolyte

Figure 2. Schematic illustration of chitosan: At low $\mathrm{pH}$ (less than about 6.0), chitosan's amine groups become protonated (polycation) and at higher $\mathrm{pH}$ (above about 6.0), chitosan's amine groups are deprotonated and reactive. 
molecular weight, concentration, ionic strength, $\mathrm{pH}$ and temperature. Viscosity is an important factor in determining chitosan's commercial applications. Viscosity of chitosan is closely related to its molecular weight. High molecular weight chitosan has higher viscosity than low molecular weight chitosan [52].

\section{- Solubility}

While Chitin is insoluble in most organic solvents, chitosan is readily soluble in dilute acidic solutions below pH 6.0 (Figure 2). Organic acids such as acetic, formic and lactic acids are used for dissolving chitosan. The most commonly used is $1 \%$ acetic acid solution at about $\mathrm{pH} 4.0$ as a reference. Chitosan is soluble in $1 \%$ hydrochloric acid but insoluble in sulfuric acid and phosphoric acids respectively. Solubility of Chitosan in inorganic acids is quite limited. Concentrated acetic acid solutions at high temperature can cause depolymerization of chitosan. Above pH 7.0 chitosan's solubility stability is poor [53].

\section{- Molecular Weight}

Molecular weight of native chitin is usually larger than one million Dalton, whereas commercial chitosan product has molecular weight of 1,000,000 - 1,200,000 daltons, depending on the process and grade of the product [54]. Tensile strength, tensile elongation, and enthalpy of the membrane prepared from high molecular weight chitosans are higher than those from low molecular weight. However, the permeability show membranes prepared from high molecular weight chitosans are lower than that from those of low molecular weight [55].

\subsection{Banana Fiber (Musa Paradisiaca)}

Banana (Musa paradisiaca, family Musaceae) is a major fruit crop of the tropical and subtropical regions of the world grown on about 8.8 million hectares [56]. Banana fiber (Table 1), a ligno-cellulosic fiber, obtained from the pseudo-stem of banana plant (Musa sepientum), is a bast fiber with relatively good mechanical properties. Banana plant is a large perennial herb with leaf sheaths that form pseudo stem. A good number of methods have so far been studied for the extraction of banana fiber. Anaerobic digestion of soft tissues of banana wastes separated fibers [57]. The extracted banana fiber has been studied for reinforcing material for lignocellulosic composite materials [58] [59] [60], pulp [61], cellulose microfibrils [62] [63]. Spin ability of banana fiber, fineness and tensile strength make it usable in a number of different textiles with different weights and thicknesses, based on what part of the banana stem the fiber was extracted from. Enzymatic treatment of extracted banana fibers spinning showed suitability of yarns production [64]. The extraction can be done mainly in three ways: manual, chemical and mechanical.

\section{Characteristics of Banana Fibers}

Banana fiber (Table 1) has its own physical and chemical characteristics and many other properties that make it a fine quality fiber.

- Appearance of banana fiber is similar to that of bamboo fiber and ramie fiber, but its fineness and spun ability is better than the two. 
Table 1. List of chemicals and raw materials.

\begin{tabular}{cccc}
\hline Name of materials & Trade Name & Company & Origin \\
\hline Prawn shell & Chitosan & Hatchery of Satkhira District, Khulna & Bangladesh \\
Banana fiber & Banana fiber & Local banana source & Bangladesh \\
Sodium hydroxide & Caustic Soda & Loba Chemie Pvt. Ltd., 107, Mumbai & India \\
Acid & Hydrochloric acid & Merck KGaA, 64271 Damstadt & Germany \\
& Acetic Acid & E. Merck, D-6100 Damstadt & Germany \\
& Sulphuric Acid & Merck KGaA, 64271 Damstadt & Germany \\
& Nitric Acid & Merck KGaA, 64271 Damstadt & Germany \\
& Potassium dichromate & Loba Chemie Pvt. Ltd., 107, Mumbai & India \\
Oxidizing agent & Distilled Water & Laboratory & Bangladesh \\
\hline
\end{tabular}

- The chemical composition of banana fiber is cellulose, hemicellulose, and lignin.

- It is highly strong fiber.

- It has smaller elongation.

- It has somewhat shiny appearance depending upon the extraction \& spinning process.

- It is light weight.

- It has strong moisture absorption quality. It absorbs as well as releases moisture very fast.

- It is biodegradable and has no negative effect on environment and thus can be categorized as eco-friendly fiber.

- Its average fineness is $2400 \mathrm{Nm}$.

- It can be spun through almost all the methods of spinning including ring spinning, open-end spinning, bast fiber spinning, and semi-worsted spinning among others.

\subsection{Areca Fiber}

Areca is a genus of about 50 species of palms in the family Arecaceae, found in humid tropical forests from China and India, across Southeast Asia to Melanesia [65]. The husk fiber is composed of cellulose with varying proportions of hemicelluloses $(35 \%-64.8 \%)$, lignin $(13.0 \%-26.0 \%)$, pectin and proto-pectin [66] [67]. The average filament length $(4 \mathrm{~cm})$ of the areca husk fiber is too short compared to other bio fibers. Mainly two types of filaments are present one very coarse and the other very fine. Unlike other traditional synthetic fibers, such as glass and carbon these areca fiber are able to impact certain benefits to the composites, including low density, high stiffness, low cost, renewability, biodegradability, and a high degree of flexibility during processing.

\section{Characteristics of Areca Fibers}

Areca fiber (Table 1) has its own physical and chemical characteristics and 
many other properties that make it a fine quality fiber.

- The chemical composition of Areca fiber is hemicellulose, and lignin.

- It is highly strong fiber.

- It has smaller elongation.

- It is light weight than synthetic fiber.

- It has strong moisture absorption quality. It absorbs as well as releases moisture very fast.

- It has low density, high stiffness, low cost, renewability, biodegradability, and a high degree of flexibility during processing.

- It can be spun through almost all the methods of spinning including ring spinning, rotor spinning.

\section{Experimental (Materials and Methodology)}

\subsection{Materials}

\section{Raw Materials and Chemicals}

Prawn shell: Collected from local Prawn Hatchery of Satkhira District, Khulna Division, Bangladesh. Raw banana and areca fiber are collected from local source.

\subsection{Methodology}

\section{Preparation of Standard Solution of Chromium}

Potassium dichromate $\left(\mathrm{K}_{2} \mathrm{Cr}_{2} \mathrm{O}_{7}\right)$ is used as the source for chromium stock solution. All the required solutions were prepared with analytical reagents and double-distilled water. $2.835 \mathrm{~g}$ of $99 \% \mathrm{~K}_{2} \mathrm{Cr}_{2} \mathrm{O}_{7}$ is dissolved in distilled water of 1.0L volumetric flask up to the mark to obtain $1000 \mathrm{ppm}(\mathrm{mg} / \mathrm{L})$ of $\mathrm{Cr}(\mathrm{VI})$ stock solution. Synthetic samples of different concentrations of $\mathrm{Cr}(\mathrm{VI})$ are prepared from this stock solution by appropriate dilutions.

$$
\text { Cr equvalent to } 1 \mathrm{gm}=\frac{\text { Moleculer weight of } \mathrm{K}_{2} \mathrm{Cr}_{2} \mathrm{O}_{7} \times 100}{\text { Atomic weight of } \mathrm{Cr} \times \text { Purity } \times 2}
$$

\subsection{Working Procedure}

\subsubsection{Preparation of Composites}

To prepare the composite of chitosan and fiber $1 \%(\mathrm{w} / \mathrm{v})$ chitosan solution was prepared by dissolving chitosan in a $1 \%(\mathrm{v} / \mathrm{v})$ aqueous acetic acid solution and stirred with magnetic stirrer for 30 minutes to dissolve chitosan. Then 1 gm fiber was added to the chitosan solution. The mixture was stirred at $30^{\circ} \mathrm{C}$ for $30 \mathrm{mi}-$ nutes so that fiber was treated with chitosan. After that fiber was filtered from chitosan solution by what-man filter paper and oven dried for 24 hours at $60^{\circ} \mathrm{C}$.

\subsubsection{Batch Studies}

Batch experiments were carried out to evaluate the influence of $\mathrm{pH}$, contact time and adsorbent dose on removal of chromium from solution. For $\mathrm{pH}$ optimization experiments were carried out by adding $40 \mathrm{mg}$ of adsorbents in $100 \mathrm{ml}$ chromium solution $(40 \mathrm{ppm})$ at a temperature of $30^{\circ} \mathrm{C}$ at $120 \mathrm{rpm}$ on a rotary shaker for $120 \mathrm{~min}$. The initial $\mathrm{pH}$ of $\mathrm{Cr}$ (IV) solution was adjusted to different 
$\mathrm{pH}$ values (2.50, 3.00, 3.50, 4.00 and 4.50) and was adjusted by dilute hydrochloric acid and sodium hydroxide using a $\mathrm{pH}$ meter (DELTA-320). For determination of effect of contact time on adsorption, assessments were done by $40 \mathrm{mg}$ of adsorbents in $100 \mathrm{ml}$ chromium solution (40 ppm) at a temperature of $30^{\circ} \mathrm{C}$ at $120 \mathrm{rpm}$ on a rotary shaker. The samples were withdrawn from the shaker at predetermined time intervals $(30,60,90,120,150$ and $180 \mathrm{~min})$. For dose optimization, $100 \mathrm{ml} 40 \mathrm{ppm}$ stock solution of $\mathrm{Cr}$ was taken in $250 \mathrm{~mL}$ conical flask at optimum pH. Different doses like 20,40,60, 80, 100, 120 and $140 \mathrm{mg}$ of adsorbent was added in each of the solution and agitated at $30^{\circ} \mathrm{C}$ in a reciprocating shaker at a fixed speed of $120 \mathrm{rpm}$ for $12 \mathrm{~min}$. After adsorption, adsorbents were separated from the solution by centrifugation method at $5000 \mathrm{rpm}$ for $10 \mathrm{~min}$. All experiments were replicated and the average results were used in data analysis. The amount of Chromium adsorbed per unit adsorbent fiber or materials was calculated according to the following equations.

$$
\begin{gathered}
\text { \% Removal }=\frac{C_{o}-C_{c}}{C_{o}} \times 100 \quad \text { [69] } \\
Q=\frac{C_{o}-C_{e}}{M} \times V \quad[70]
\end{gathered}
$$

Here, $Q$ is adsorption capacity metal ion absorbed per gram of adsorbent, $C_{o}$ and $C_{e}$ is the initial and final concentration respectively, $M$ is the mass of the adsorbent (in $\mathrm{mg}$ ) and $v$ is the volume of chromium solution taken for the adsorption study (in liter).

\section{Results and Discussion}

\subsection{Assessment of Adsorption Analysis of Chitosan, Banana and Areca Fiber}

The FT-IR spectra corresponding to chitosan, banana, areca fiber and their comparison are shown in Figure 3 and Figure 4 . The peak around $3350 \mathrm{~cm}^{-1}$ observed due to $-\mathrm{OH}$ stretching. Table 2 and Figure 3 show the $\mathrm{C}-\mathrm{H}$ stretching vibration
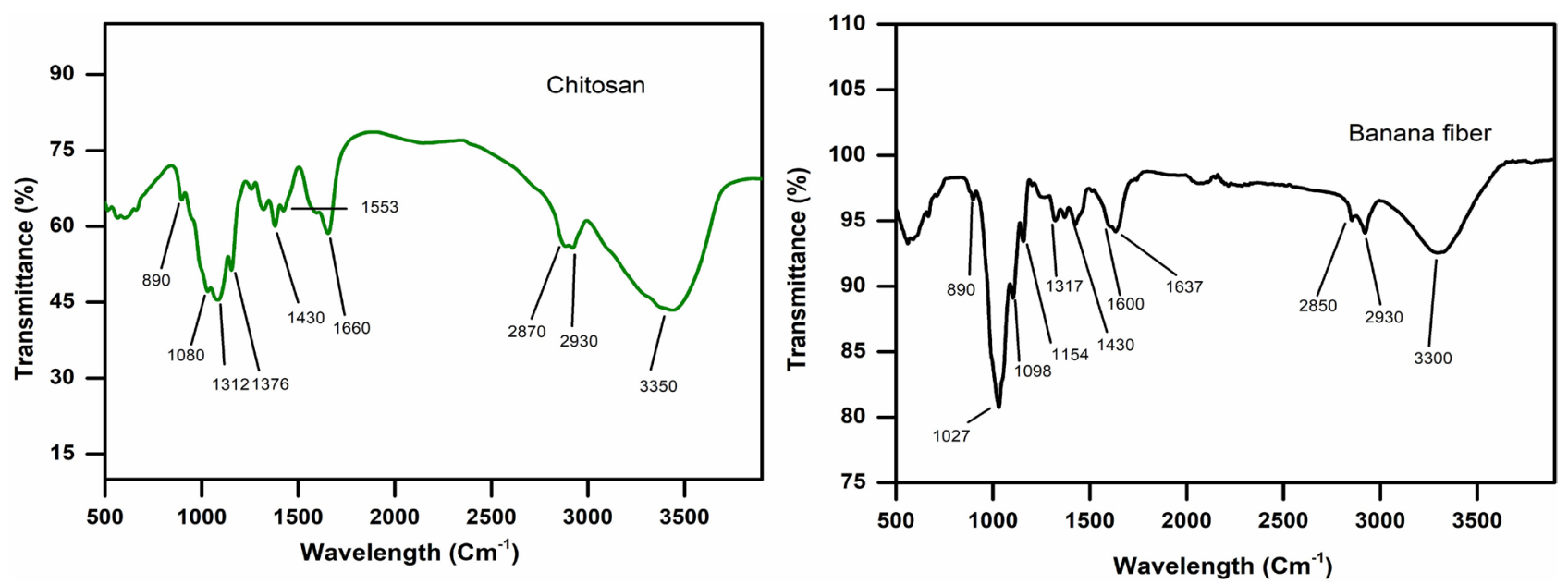

Figure 3. FTIR of chitosan and banana fiber. 


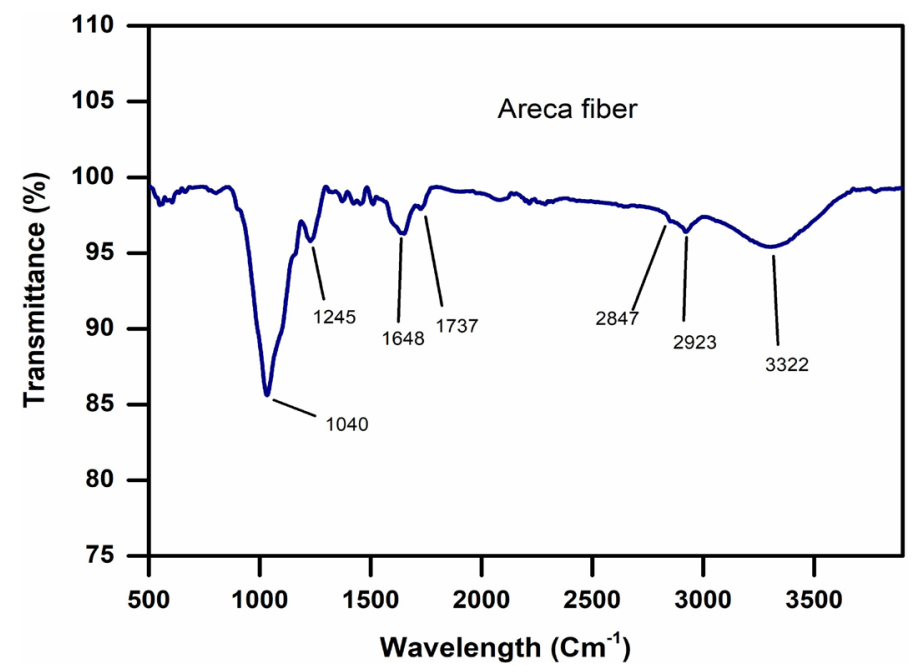

Figure 4. FTIR of areca fiber.

Table 2. FTIR wave number analysis.

\begin{tabular}{cccc}
\hline Wave length Description & $\begin{array}{c}\text { Chitosan } \\
\text { Wavelength }\left(\mathrm{cm}^{-1}\right)\end{array}$ & $\begin{array}{c}\text { Areca Fiber } \\
\text { Wavelength }\left(\mathrm{cm}^{-1}\right)\end{array}$ & $\begin{array}{c}\text { Banana Fiber } \\
\text { Wavelength }\left(\mathrm{cm}^{-1}\right)\end{array}$ \\
\hline N-H bending & 1553,1660 & 1508,1648 & 1637 \\
O-H stretching & 3350 & 3322 & 3300 \\
$-\mathrm{CH}_{2}$ and $-\mathrm{CH}_{3}$ Stretching & 2930 & 2923 & 2930 \\
$\mathrm{C}-\mathrm{H}$ bending of $\mathrm{CH}_{2}$ group & 1376 & 1245 & 1317 \\
$\mathrm{C}-\mathrm{C}-\mathrm{O}$ stretching & 1130 & - & 1154 \\
$\mathrm{C}_{6}-\mathrm{O}$ stretching & 1080 & 1040 & 1027 \\
$-\mathrm{C}-\mathrm{O}$ stretching & 1430 & - & 1430 \\
$\mathrm{C}=\mathrm{O}$ stretching & - & - & 1740,1637
\end{tabular}

of the polymer backbone is demonstrated through strong peak at $2930 \mathrm{~cm}^{-1}$ and $2850 \mathrm{~cm}^{-1}$. However, peaks at $1376 \mathrm{~cm}^{-1}, 1130 \mathrm{~cm}^{-1}$ and $1080 \mathrm{~cm}^{-1}$ are observed due to asymmetrical $\mathrm{C}-\mathrm{H}$ bending of the $\mathrm{CH}_{2}$ group, $\mathrm{C}_{3}-\mathrm{O}$ stretching and $\mathrm{C}_{6}-\mathrm{O}$ stretching overlapped with $\mathrm{C}=\mathrm{O}$ stretch vibration respectively. The transmittance bands at $1430 \mathrm{~cm}^{-1}$ appeared to $-\mathrm{C}-\mathrm{O}$ stretching of primary alcoholic group in chitosan (Table 2).

A broad and strong band at $3300 \mathrm{~cm}^{-1}$ was assigned to the vibration stretching of the hydroxyl group. The absorption band at $2930 \mathrm{~cm}^{-1}$ can be attributed to $\mathrm{C}-\mathrm{H}$ stretching of the methyl and methylene groups (Table 2). The bands at $1637 \mathrm{~cm}^{-1}$ which can be ascribed to vibrational stretching of unconjugated $\mathrm{C}=\mathrm{O}$ groups, mainly due to hemicellulose and to conjugated carbonyl present in the lignin, respectively, were prominent in the untreated banana fiber.

After alkaline treatment, the band at $1740 \mathrm{~cm}^{-1}$ was found to be almost absent in the treated fiber spectrum (Table 2 and Figure 4). In addition, the absorption intensity at $1154 \mathrm{~cm}^{-1}$ assigned to $\mathrm{C}-\mathrm{O}$ stretching of acetyl groups in the hemicellulose decreased with alkaline treatment. These results suggest a reduction in 
the hemicellulose and lignin content following alkaline treatment of the fibers, as reported previously for banana fibers. Table 2 and Figure 4 show the transmittance bands at $1154 \mathrm{~cm}^{-1}$ appeared to $\mathrm{C}-\mathrm{C}-\mathrm{O}$ stretching and $1430 \mathrm{~cm}^{-1}$ appeared to $-\mathrm{C}-\mathrm{O}$ stretching of primary alcoholic group in areca fiber.

\subsection{Adsorption of Heavy Metal Chromium by Raw Banana Fiber, Raw Areca Fiber and Chitosan Treated Fiber (Banana and Areca) at Different Parameter}

In Figures 5-10, we showed the adsorption capacity and the value of adsorbed $\mathrm{Cr}$ from the waste water. The measurement variables were $\mathrm{pH}$, time (minutes) and adsorbent dose or amount in $\mathrm{mg}$.

\subsubsection{Effect of $\mathrm{pH}$ on the Adsorption of Heavy Metal Chromium} $100 \mathrm{ml} 40 \mathrm{ppm}$ stock solution of $\mathrm{Cr}$ was taken in $250 \mathrm{~mL}$ conical flask at different $\mathrm{pH}$ condition. $40 \mathrm{mg}$ of adsorbent was added in each of the solution and agitated at $27^{\circ} \mathrm{C}$ in a reciprocating shaker at a fixed speed of $140 \mathrm{rpm}$ for 2 hours. After 2 hours the solution was filtered off through Whatman 41 filter paper and concentration of $\mathrm{Cr}$ was determined by Atomic Absorption Spectroscopic (AAS) method. The removal of $\mathrm{Cr}$ from waste water by adsorption is highly depend on $\mathrm{pH}$ of the solution, which affects the surface charge of the adsorbent, the degree of ionization, and the speciation of the adsorbent species. It was therefore important to study the effect of $\mathrm{pH}$ on the adsorption of Cr. Adsorption was determined over the $\mathrm{pH}$ range 2.5 to 4.5 . The results obtained are presented in Figure 5 and Figure 8. $\mathrm{Cr}$ forms stable complexes such as $\mathrm{Cr}_{2} \mathrm{O}_{7}^{2-}, \mathrm{HCrO}_{4}^{-}$, $\mathrm{CrO}_{4}^{2+}$, and $\mathrm{HCr}_{2} \mathrm{O}_{7}^{-}$, the fraction of any particular species is dependent upon the chromium concentration and $\mathrm{pH}$ [71]. The experimentally observed decrease in the $\mathrm{Cr}$ removal at a higher $\mathrm{pH}$ can be explained by the rapid changes in protonated and un-protonated forms of banana and areca. The optimum $\mathrm{pH}$ was found 4.5 respectively chitosan treated banana and areca fiber in Figure 8. The standard deviation value of adsorbed $\mathrm{Cr}$ by raw chitosan, untreated banana and areca of pH test results were 9.399, 1.072 and $0.728 \mathrm{ppm}$ respectively. On the other hand, the standard deviation result of $\mathrm{pH}$ tests for treated banana and areca fiber were 1.831 and $3.293 \mathrm{ppm}$ congruently.

\subsubsection{Effect of Time on the Adsorption of Heavy Metal Chromium}

$100 \mathrm{ml} 40 \mathrm{ppm}$ stock solution of Cr was taken in $250 \mathrm{~mL}$ conical flask at $3.5 \mathrm{pH}$ condition. $40 \mathrm{mg}$ of adsorbent was added in each of the solution and agitated at $27^{\circ} \mathrm{C}$ in a reciprocating shaker at a fixed speed of $140 \mathrm{rpm}$ at different time (30, $60,90,120,150$ and 180 minutes). The relatively rapid initial rate of adsorption capacity of $\mathrm{Cr}$ on banana and areca were higher from 30 min time period. But there was a slow adsorption capacity rate was found after that time period. Because during initial time period adsorbent have higher activation or adsorption site at the same time there was higher cation (adsobate) present in the solution so that adsorption capacity was maximum. In this analysis, optimum time period 

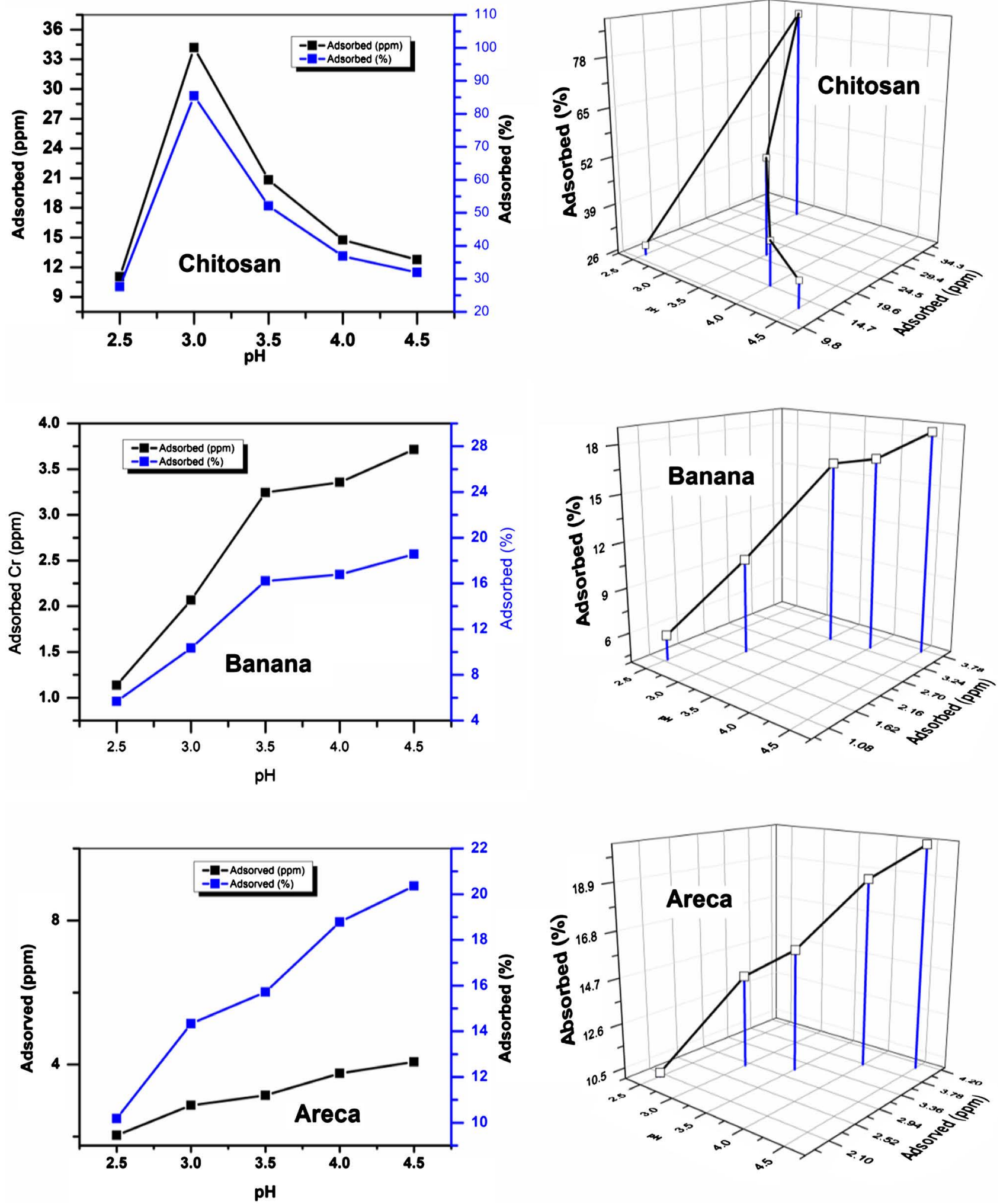

Figure 5. Effect of $\mathrm{pH}$ on the Adsorption of heavy metal chromium (VI) by raw chitosan, banana and areca fiber. 

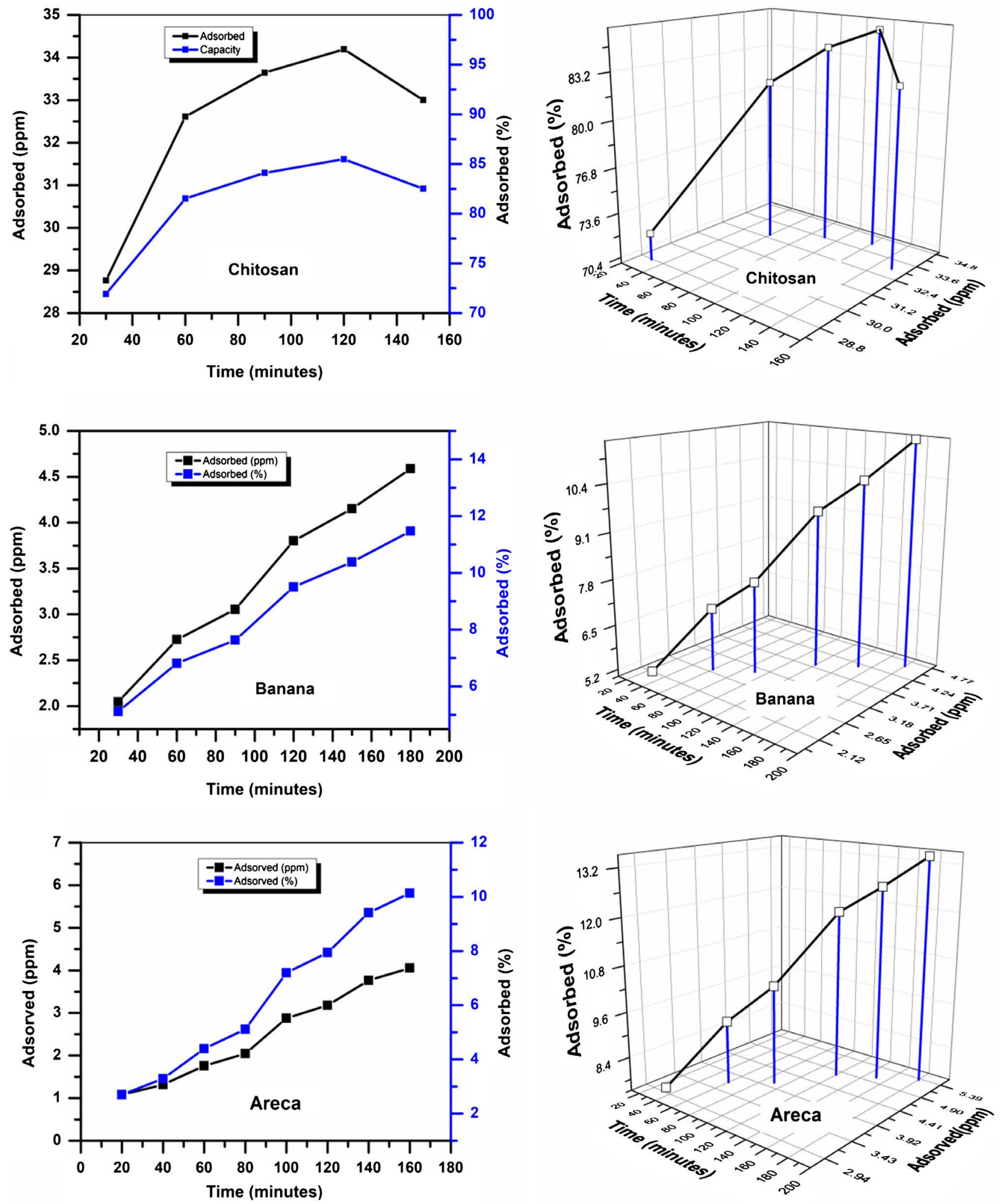

Figure 6. Effect of time on the adsorption of heavy metal chromium (VI) by raw chitosan, banana and areca fiber. 

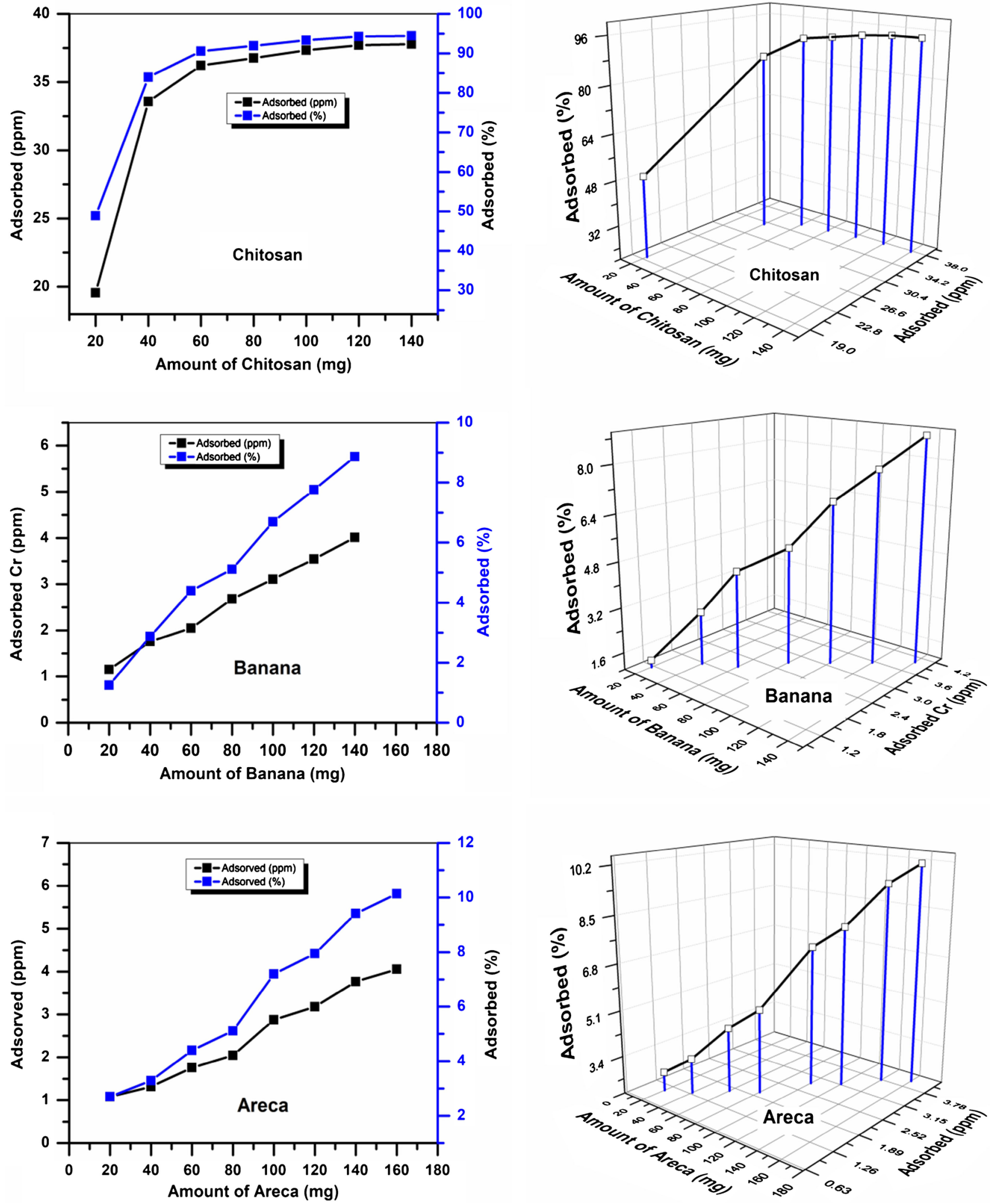

Figure 7. Effect of amount of materials (dose) on the Adsorption of heavy metal chromium (VI) by raw chitosan, banana and areca fiber. 

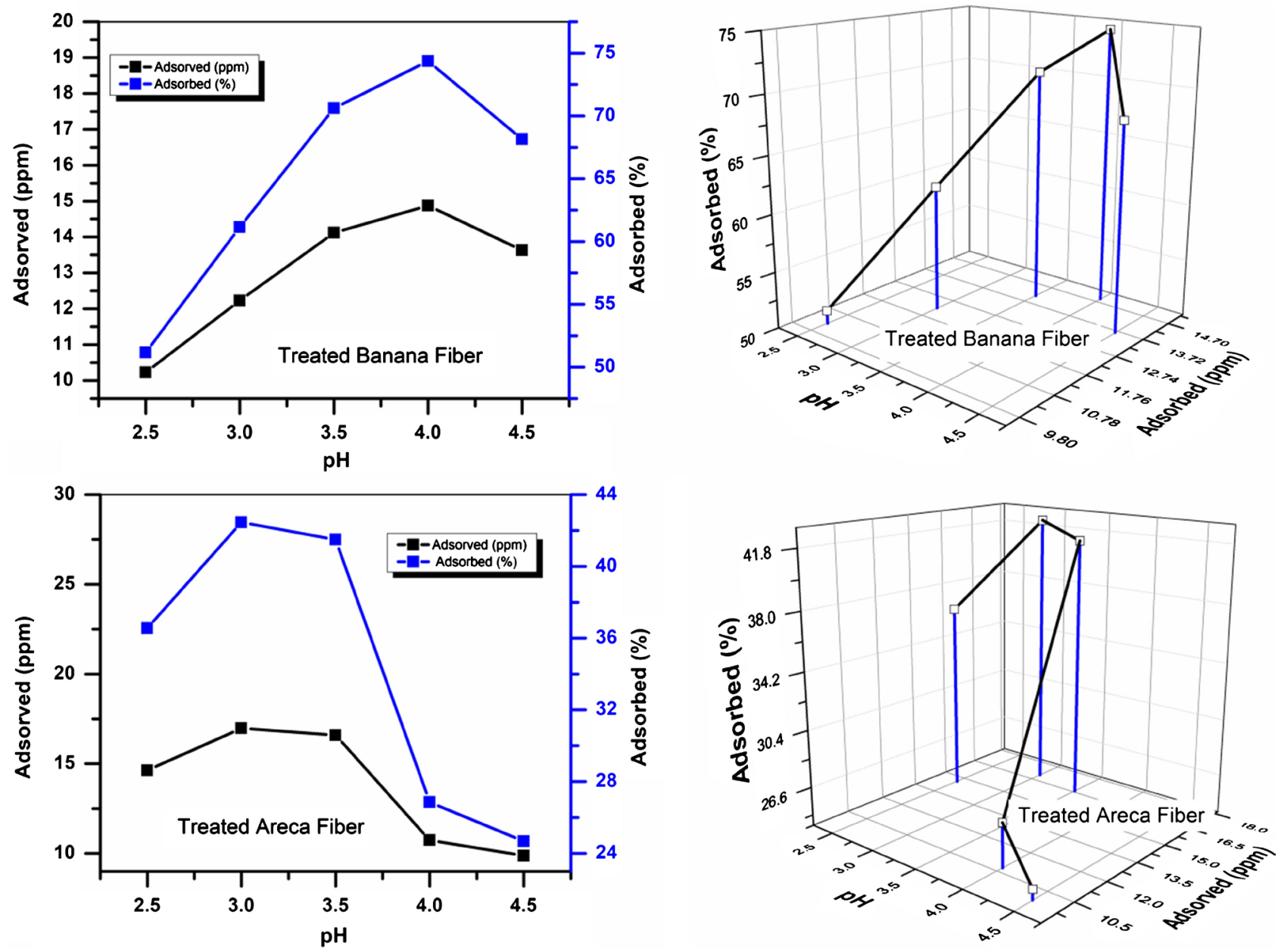

Figure 8. Effect of $\mathrm{pH}$ on the Adsorption of heavy metal chromium (VI) by chitosan treated banana fiber and areca fiber.

for adsorption was 150 minutes in Figure 6. The optimum time period was found 180 minutes chitosan treated banana and areca fiber in Figure 9. The standard deviation value of adsorbed $\mathrm{Cr}$ by raw chitosan, untreated banana and areca of time test results were $2.163,0.859$ and $0.896 \mathrm{ppm}$ respectively. On the other hand, the standard deviation result of time tests for treated banana and areca fiber were 2.693 and 2.793 ppm congruently.

\subsubsection{Effect of Adsorbent dose on the Adsorption of Heavy Metal Chromium}

$100 \mathrm{ml} 40 \mathrm{ppm}$ stock solution of Cr was taken in $100 \mathrm{~mL}$ conical flask at $3.5 \mathrm{pH}$ condition. Different dose like 20, 40, 60, 80, 100, 120 and $140 \mathrm{mg}$ of adsorbent was added in each of the solution and agitated at $27^{\circ} \mathrm{C}$ in a reciprocating shaker at a fixed speed of $140 \mathrm{rpm}$ for 2 hours. After 2 hours the solution was filtered off through what-man 41 filter paper and concentration of $\mathrm{Cr}$ was determined by Atomic Absorption Spectroscopic (AAS) method. In Figure 8 doses was $160 \mathrm{mg}$. But at the same time we have consider about how much of chromium it adsorbed. From Figure 7, it was found that maximum $3.65 \mathrm{ppm}$ and $3.78 \mathrm{ppm}$ of chromium was removed by the raw banana and areca fiber respectively. The 

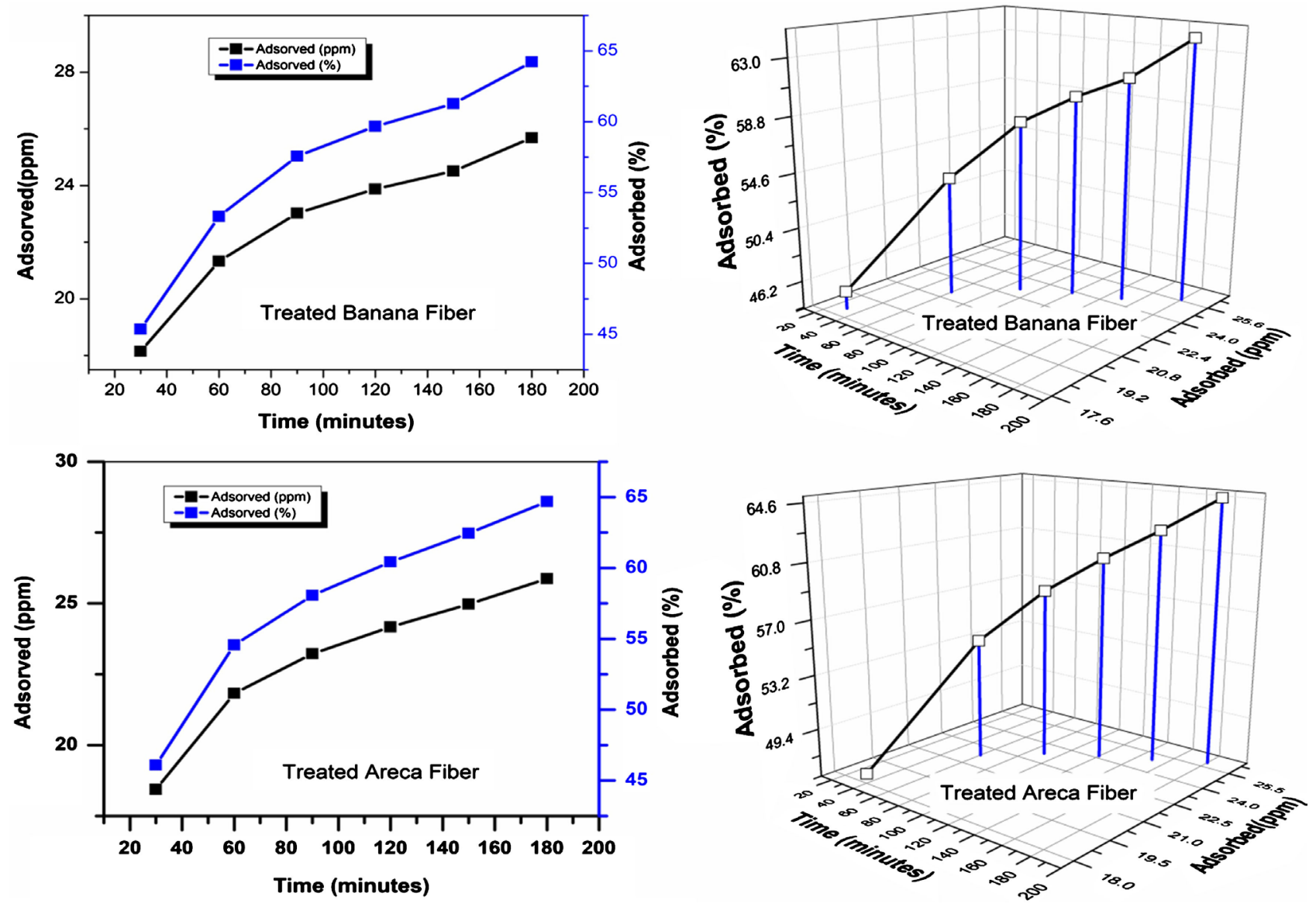

Figure 9. Effect of time on the Adsorption of heavy metal chromium (VI) by chitosan treated banana fiber and areca fiber.

optimum amount of adsorbent dose was measured of chitosan treated banana and areca fiber in Figure 10. The standard deviation value of adsorbed $\mathrm{Cr}$ by raw chitosan, untreated banana and areca of dose test results were 6.588, 0.966 and $1.211 \mathrm{ppm}$ respectively. On the other hand, the standard deviation result of adsorbent dose tests for treated banana and areca fiber were 5.469 and 4.152 ppm congruently.

From Figure 10 it was found that maximum $30.057 \mathrm{ppm}$ of chromium was removed by the chitosan treated banana fiber respectively. On the other hand, $30.156 \mathrm{ppm}$ chromium was removed by the chitosan treated areca fiber respectively. It may be due to the lower dose adsorbent have an opportunity to adsorb higher amount of $\mathrm{Cr}$ molecule as well as for larger dose only upper layer of banana and areca adsorb $\mathrm{Cr}$ and block the lower layer banana and areca molecule.

In this study, chitosan solution are used and make composite with banana and areca fiber, but all chitosan are not bind with fiber that means some chitosan has been losed during composite preparation. For that reason, we can not conform that this composites are not that composition as mentioned. Raw banana fiber has been used during analysis, it will be better if pure fiber (after scouring) will be used which will remove oil and wax. 

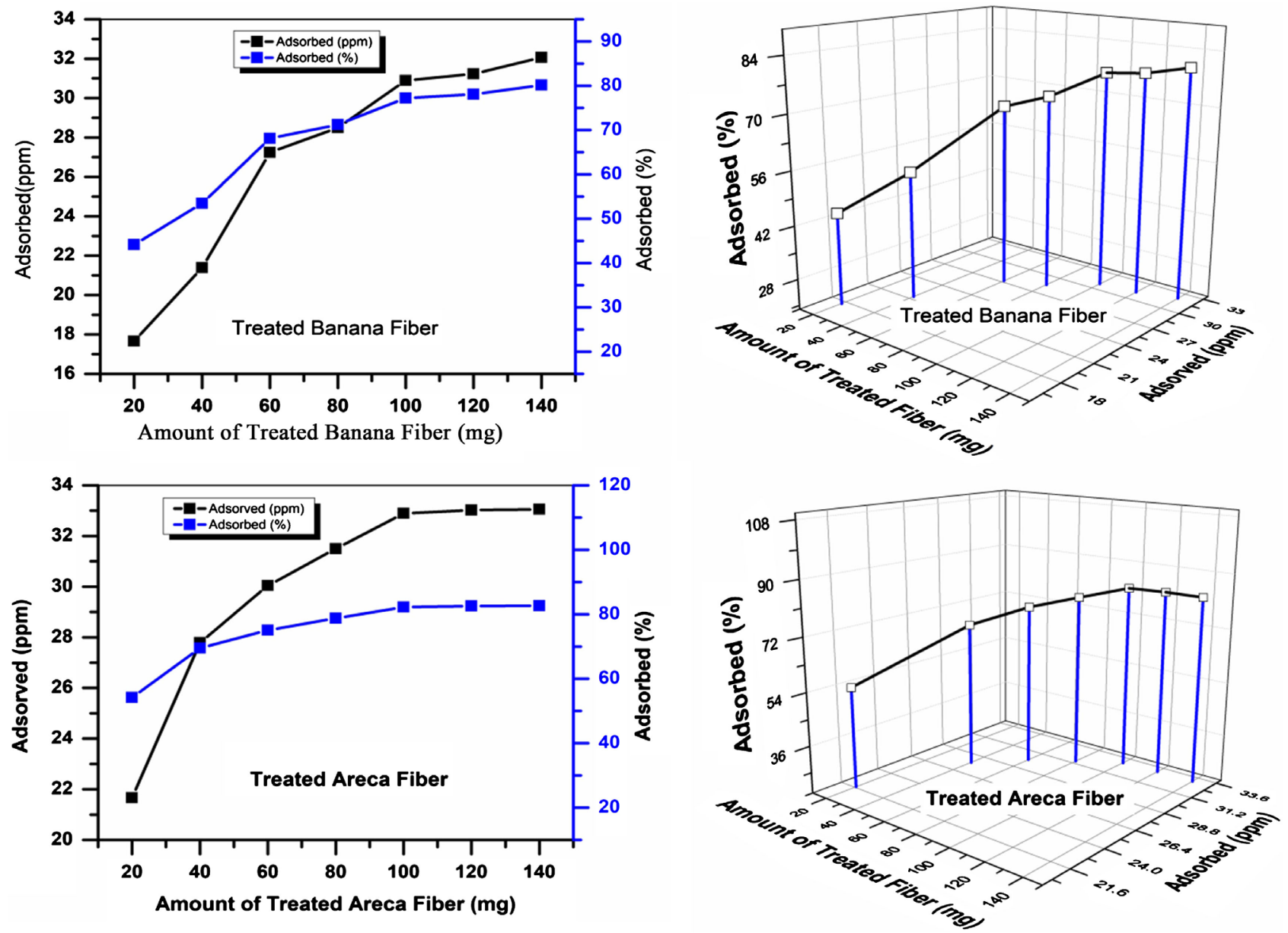

Figure 10. Effect of amount of chitosan treated fiber on the adsorption of heavy metal chromium (VI) by chitosan treated banana fiber and areca fiber.

From Figures 11-15, it was also found that Langmuir isotherm and Freundlich isotherm both of them are favorable. But Langmuir isotherm is much favorable which means adsorption of chromium in banana and areca fiber is mainly on the surface of the adsorbent and it is monolayer.
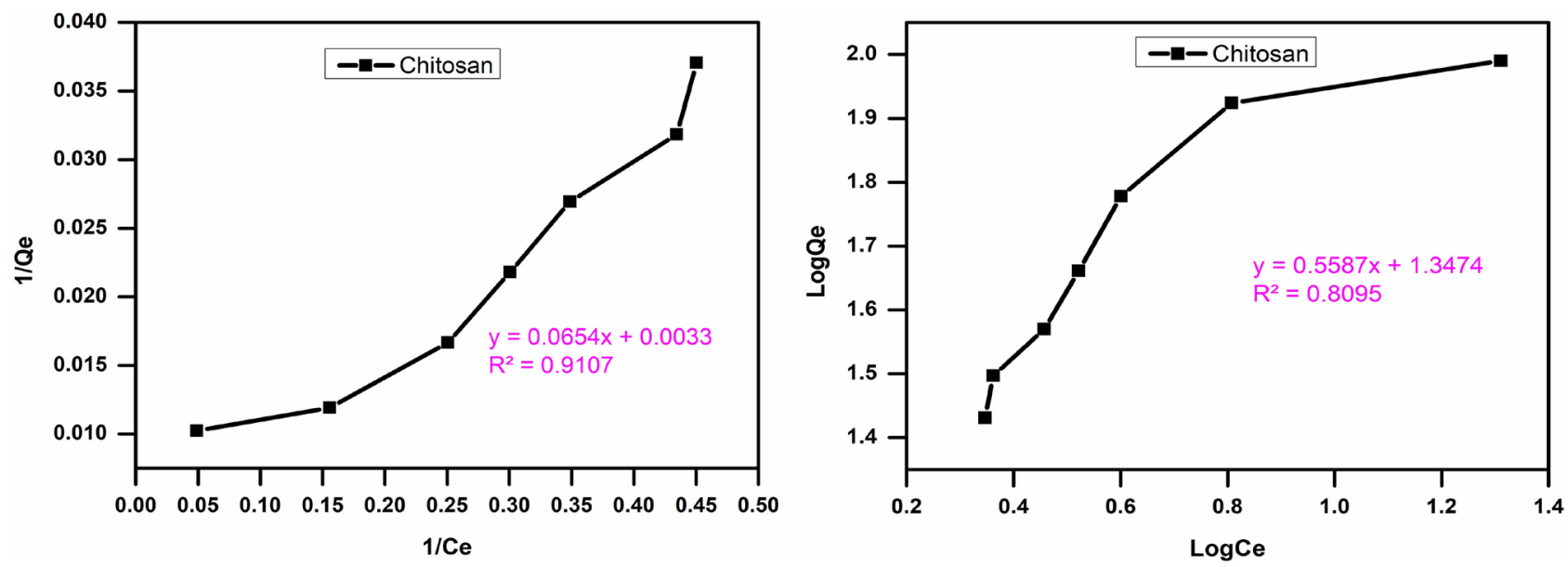

Figure 11. Adsorption isotherm for chitosan, left side figure for Langmuir and right side figure for Freundlich. 

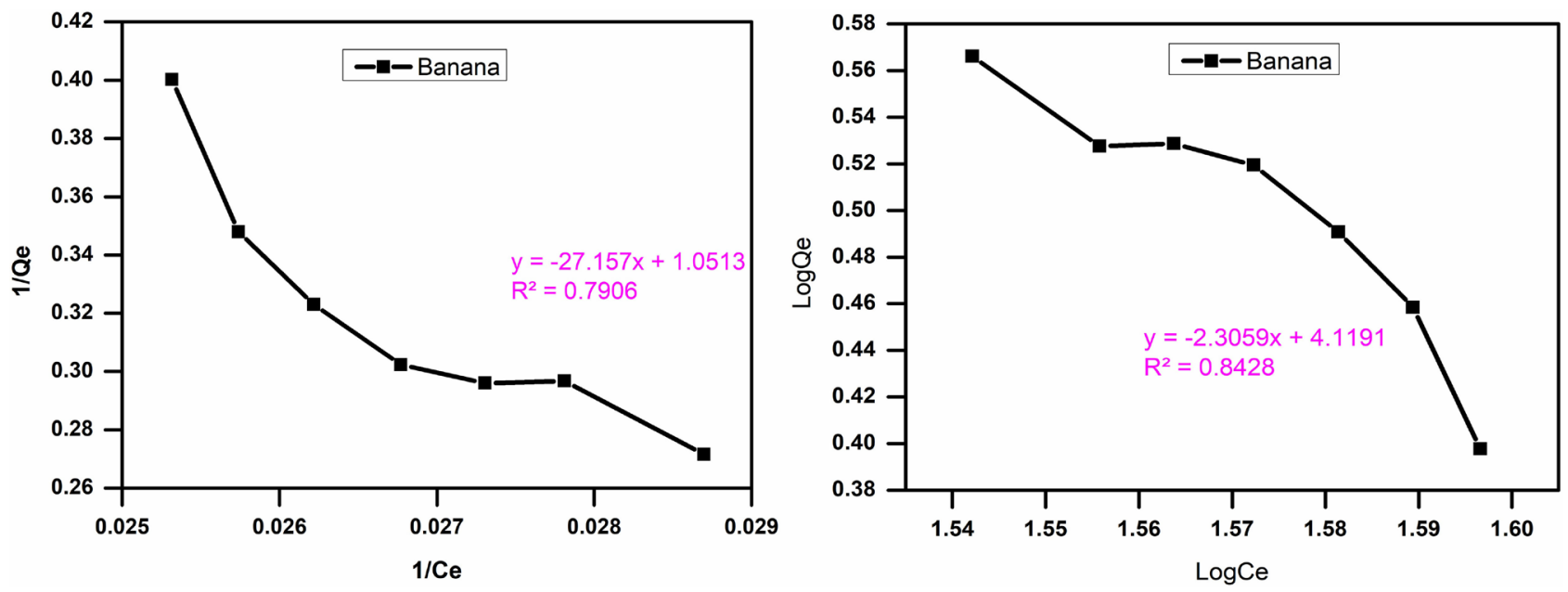

Figure 12. Adsorption isotherm for banana, left side figure for Langmuir and right side figure for Freundlich.
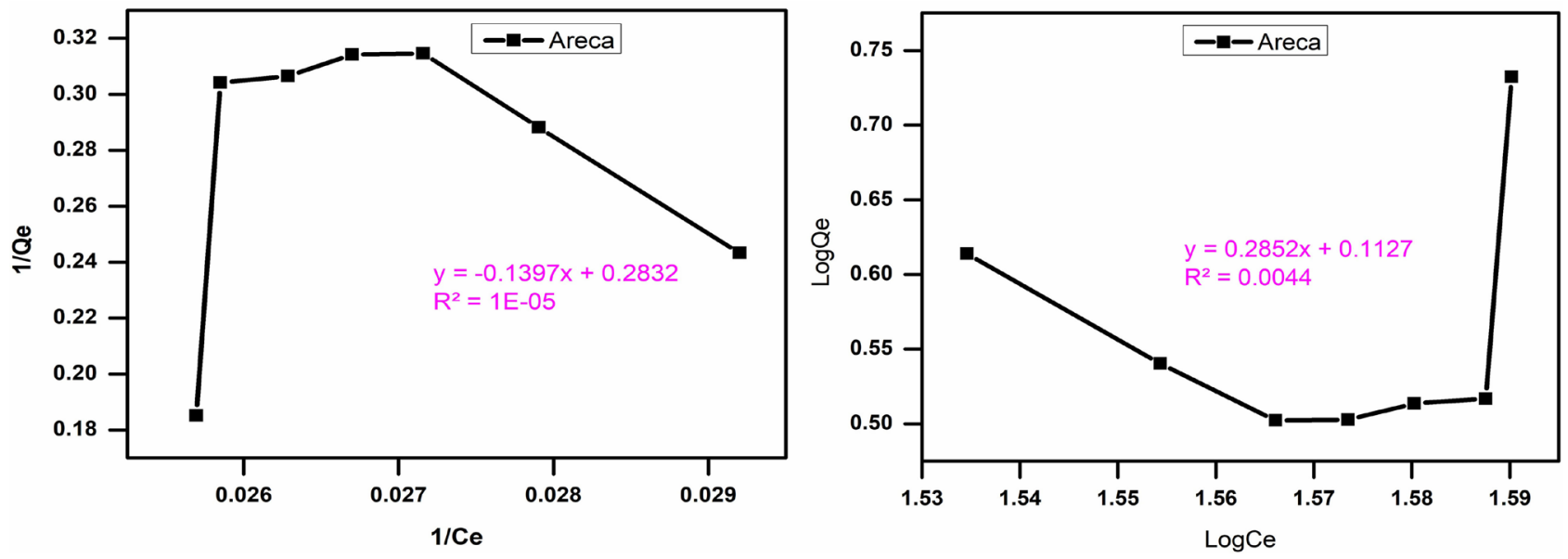

Figure 13. Adsorption isotherm for Areca, left side figure for Langmuir and right side figure for Freundlich.
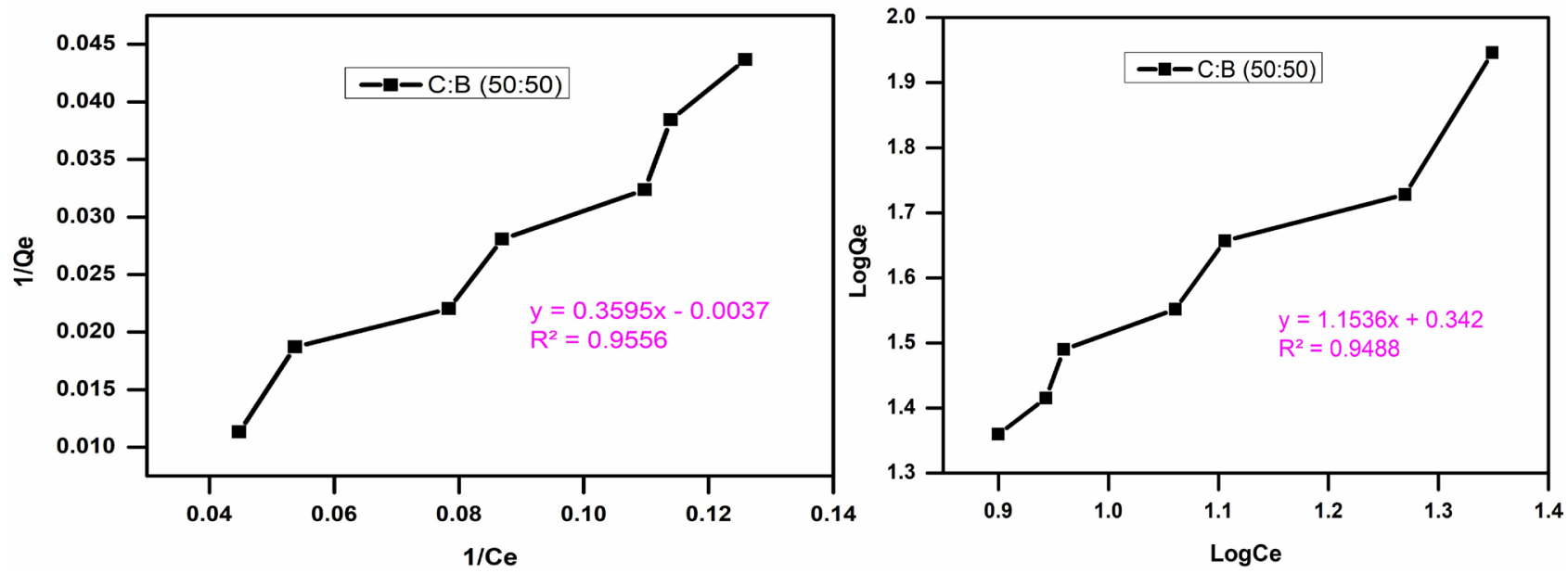

Figure 14. Adsorption isotherm for chitosan treated banana fiber (50\% chitosan (C) treated banana fiber (B), left side figure for Langmuir and right side figure for Freundlich 

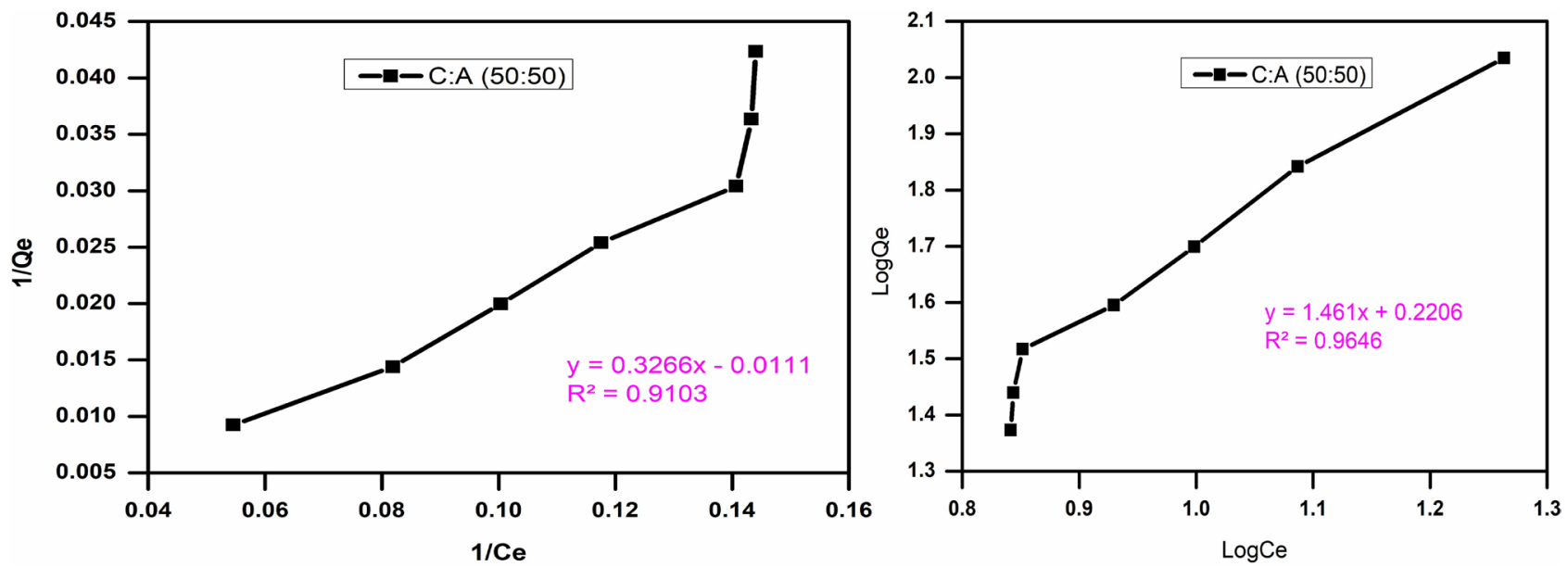

Figure 15. Adsorption isotherm for chitosan treated areca fiber (50\% chitosan(C) treated areca (A) fiber), left side figure for Langmuir and right side figure for Freundlich.

\section{Conclusion}

Chromium is highly toxic which is mainly coming from the textile and tannery industries. Hexavalent chromium is so toxic that its low concentration in drinking water and food is very harmful for any animal and plant life. For that reason, chromium removal from industrial effluents is a major concern. On the other side it also would be considered that used material must not be harmful and should biodegradable so that no residue will remain after adsorption of chromium. In this study, low cost and biodegradable composites of chitosan, banana and areca with different composition were prepared. These prepared composites were then optimized regarding $\mathrm{pH}$, time duration, and adsorbent dose and as well as isotherm study was also carried out. Though from the study it was obvious that chitosan has the maximum capacity to adsorb chromium but its stability in water at acidic condition was low and deprotonated easily. For that reason a stable matrix is required which also has adsorption capacity. In this study, it was found that areca and banana will be successful matrix because it makes composite more stable and it also has own adsorption capacity. The Langmuir and Freundlich adsorption models were used for the mathematical description of the adsorption of chromium ion onto composites and it was found that the Langmuir adsorption isotherm was more fitted models which mean that a monolayer adsorption surface was created. Further study can be investigated to remove toxic metals $(\mathrm{Pb}, \mathrm{Cd}, \mathrm{As}, \mathrm{Cu})$ which are available into the environment. Fiber from different source can be used to make different composite. However, areca/banana/chitosan composites in different ratio can be used to remove toxic metals. Reaction kinetics between composites with toxic metals can be investigated on different ratio of chitosan and fiber (banana and areca).

\section{Acknowledgements}

The authors would like to express thank and gratitude towards Bangladesh 
Atomic Energy Commission (BARC), Bangladesh University of Textiles (BUTEX) and National Institute of Textile Engineering and Research (NITER) for providing machineries and equipment on time during the course of this research and for other assistance that made this work possible. The authors declare that they have no conflict of interest.

\section{Conflicts of Interest}

The authors declare no conflicts of interest regarding the publication of this paper.

\section{References}

[1] Belkacem, M., Khodir, M. and Abdelkrim, S. (2008) Treatment Characteristics of Textile Wastewater and Removal of Heavy Metals Using the Electroflotation Technique. Desalination, 228, 245-254. https://doi.org/10.1016/j.desal.2007.10.013

[2] Dey, S. and Islam, A. (2015) A Review on Textile Wastewater Characterization in Bangladesh. Resources and Environment, 5, 15-44.

[3] Uddin, A.N.M.M. and Ahmed, S.A. (2018) Heavy Metal Contamination of Soil and Health Hazards Among the Residents of Tannery Industrial Area. Anwer Khan Modern Medical College Journal, 9, 39-43. https://doi.org/10.3329/akmmcj.v9i1.35823

[4] Ku, Y. and Jung, I.-L. (2001) Photocatalytic Reduction of Cr(VI) in Aqueous Solutions by UV Irradiation with the Presence of Titanium Dioxide. Water Research, 35, 135-142. https://doi.org/10.1016/S0043-1354(00)00098-1

[5] Fu, F. and Wang, Q. (2011) Removal of Heavy Metal Ions from Wastewaters: A Review. Journal of Environmental Management, 92, 407-418. https://doi.org/10.1016/j.jenvman.2010.11.011

[6] Alyüz, B. and Veli, S. (2009) Kinetics and Equilibrium Studies for the Removal of Nickel and Zinc from Aqueous Solutions by Ion Exchange Resins. Journal of Hazardous Materials, 167, 482-488. https://doi.org/10.1016/j.jhazmat.2009.01.006

[7] El Samrani, A., Lartiges, B. and Villiéras, F. (2008) Chemical Coagulation of Combined Sewer Overflow: Heavy Metal Removal and Treatment Optimization. Water Research, 42, 951-960. https://doi.org/10.1016/j.watres.2007.09.009

[8] Lundh, M., Jönsson, L. and Dahlquist, J. (2000) Experimental Studies of the Fluid Dynamics in the Separation Zone in Dissolved Air Flotation. Water Research, 34, 21-30. https://doi.org/10.1016/S0043-1354(99)00136-0

[9] Athanasiadis, K. and Helmreich, B. (2005) Influence of Chemical Conditioning on the Ion Exchange Capacity and on Kinetic of Zinc Uptake by Clinoptilolite. Water Research, 39, 1527-1532. https://doi.org/10.1016/j.watres.2005.01.024

[10] Memon, J.R., Memon, S.Q., Bhanger, M.I., El-Turki, A., Hallam, K.R. and Allen, G.C. (2009) Banana Peel: A Green and Economical Sorbent for the Selective Removal of $\mathrm{Cr}(\mathrm{VI})$ from Industrial Wastewater. Colloids and Surfaces B: Biointerfaces, 70, 232-237. https://doi.org/10.1016/j.colsurfb.2008.12.032

[11] López-García, M., Lodeiro, P., Herrero, R., Barriada, J.L., Rey-Castro, C., David, C., et al. (2013) Experimental Evidences for a New Model in the Description of the Adsorption-Coupled Reduction of Cr(VI) by Protonated Banana Skin. Bioresource Technology, 139, 181-189. https://doi.org/10.1016/j.biortech.2013.04.044

[12] Ali, A., Saeed, K. and Mabood, F. (2016) Removal of Chromium (VI) from Aqueous 
Medium Using Chemically Modified Banana Peels as Efficient Low-Cost Adsorbent. Alexandria Engineering Journal, 55, 2933-2942. https://doi.org/10.1016/j.aej.2016.05.011

[13] Muslim, A., Zulfian, I.M., Devrina, E. and Fahmi, H. (2015) Adsorption of Cu(II) from the Aqueous Solution by Chemical Activated Adsorbent of Areca Catechu Shell. Journal of Engineering Science and Technology, 10, 1654-1666.

[14] Bhattacharyya, K.G. and Gupta, S.S. (2008) Adsorption of a Few Heavy Metals on Natural and Modified Kaolinite and Montmorillonite: A Review. Advances in Colloid and Interface Science, 140, 114-131. https://doi.org/10.1016/j.cis.2007.12.008

[15] Mohan, D. and Chander, S. (2006) Removal and Recovery of Metal Ions from Acid Mine Drainage Using Lignite-A Low Cost Sorbent. Journal of Hazardous Materials, 137, 1545-1553. https://doi.org/10.1016/j.jhazmat.2006.04.053

[16] Apiratikul, R. and Pavasant, P. (2008) Sorption of $\mathrm{Cu}^{2+}, \mathrm{Cd}^{2+}$, and $\mathrm{Pb}^{2+}$ Using Modified Zeolite from Coal Fly Ash. Chemical Engineering Journal, 144, 245-258. https://doi.org/10.1016/j.cej.2008.01.038

[17] Akter, S. and Ahammed, S. (2018) Analysis on Garments Buying Behavior of Textile Engineering Students: A Study in Bangladesh.

[18] Fathima, N., Rao, R. and Nair, B.U. (2012) Tannery Solid Waste to Treat Toxic Liquid Wastes: A New Holistic Paradigm. Environmental Engineering Science, 29, 363-372. https://doi.org/10.1089/ees.2010.0445

[19] Paul, R. and Quadir, S. (2013) Bangladesh Urges No Harsh EU Measures over Factory Deaths. Reuters, Dhaka.

[20] Paul, H., Antunes, A.P.M., Covington, A.D., Evans, P. and Phillips, P.S. (2013) Bangladeshi Leather Industry: An Overview of Recent Sustainable Developments. Journal of the Society of Leather Technologists and Chemists, 97, 25-32.

[21] Brown, E., Marmer, W., Carrio, R., Celma, P., Cot, J., Taylor, M.M., et al. (1998) Processing of Leather Waste: Pilot Scale Studies on Chrome Shavings. Part I Isolation and Characterization of Protein Products and Separation of Chrome Cake. Journal of the American Leather Chemists' Association, 92, 61.

[22] Langmaier, F., Kolomaznik, K., Sukop, S. and Mladek, M. (1999) Products of Enzymatic Decomposition of Chrome-Tanned Leather Waste. Journal of the Society of Leather Technologists and Chemists, 83, 187-195.

[23] Veeger, L. (1993) Ecological Procedure to Solve the Tannery Waste Problems-Invited Lecture. Journal of the American Leather Chemists Association, 88, 326-329.

[24] Rahaman, A., Hosen, M.R., Bashar, K., Afroze, J.S. and Naher, U.B.H. (2016) Extraction of Chromium from Leather Chrome Shaving Dust. International Journal of Scientific \& Technology Research, 5, 160-163.

[25] Kanagaraj, J., Velappan, K., Chandra Babu, N. and Sadulla, S. (2006) Solid Wastes Generation in the Leather Industry and Its Utilization for Cleaner Environment: A Review. Journal of Scientific and Industrial Research, 65, 541-548. https://doi.org/10.1002/chin.200649273

[26] Sekomo, C.B., Rousseau, D.P., Saleh, S.A. and Lens, P.N. (2012) Heavy Metal Removal in Duckweed and Algae Ponds as a Polishing Step for Textile Wastewater Treatment. Ecological Engineering, 44, 102-110. https://doi.org/10.1016/j.ecoleng.2012.03.003

[27] Halimoon, N. and Yin, R.G.S. (2010) Removal of Heavy Metals from Textile Wastewater Using Zeolite. Environment Asia, 3, 124-130. 
[28] Harlan, J. and Feairheller, S. (1977) Chemistry of the Crosslinking of Collagen during Tanning. In: Protein Crosslinking, Springer, Berlin, 425-440. https://doi.org/10.1007/978-1-4684-3282-4_27

[29] Heidemann, E. (1982) Newer Developments in the Chemistry and Structure of Collagenous Connective Tissues and Their Impact on Leather Manufacture. Journal of the Society of Leather Technologists and Chemists, 66, 21-29.

[30] Covington, A.D. (1997) Modern Tanning Chemistry. Chemical Society Reviews, 26, 111-126. https://doi.org/10.1039/cs9972600111

[31] Donaldson, R.M. and Barreras, R.F. (1966) Intestinal Absorption of Trace Quantities of Chromium. Journal of Laboratory and Clinical Medicine, 68, 484-493.

[32] Foa, V., Riboldi, L., Patroni, M., Zocchetti, C., Sbrana, C. and Mutti, A. (1988) Effects Derived from Long-Term Low-Level Chromium Exposure in Ferro-Alloy Metallurgy. Study of Absorption and Renal Function in Workers. Science of the Total Environment, 71, 389-400. https://doi.org/10.1016/0048-9697(88)90211-2

[33] Aitio, A., Järvisalo, J., Kiilunen, M., Tossavainen, A. and Vaittinen, P. (1984) Urinary Excretion of Chromium as an Indicator of Exposure to Trivalent Chromium Sulphate in Leather Tanning. International Archives of Occupational and Environmental Health, 54, 241-249. https://doi.org/10.1007/BF00379053

[34] Kiilunen, M., Kivistö, H., Ala-Laurila, P., Tossavainen, A. and Aitio, A. (1983) Exceptional Pharmacokinetics of Trivalent Chromium during Occupational Exposure to Chromium Lignosulfonate Dust. Scandinavian Journal of Work, Environment \& Health, 9, 265-271. https://doi.org/10.5271/sjweh.2410

[35] Mertz, W. (1969) Chromium Occurrence and Function in Biological Systems. Physiological Reviews, 49, 163-239. https://doi.org/10.1152/physrev.1969.49.2.163

[36] Wiegand, H., Ottenwälder, H. and Bolt, H. (1984) Disposition of Intratracheally Administered Chromium (III) and Chromium (VI) in Rabbits. Toxicology Letters, 22, 273-276. https://doi.org/10.1016/0378-4274(84)90078-X

[37] WHO (1990) Chromium (Environmental Health Criteria 61) International Programme on Chemical Safety. Geneva.

[38] Lindberg, E. and Vesterberg, O. (1983) Monitoring Exposure to Chromic Acid in Chromeplating by Measuring Chromium in Urine. Scandinavian Journal of Work, Environment \& Health, 9, 333-340. https://doi.org/10.5271/sjweh.2406

[39] Dayan, A. and Paine, A. (2001) Mechanisms of Chromium Toxicity, Carcinogenicity and Allergenicity: Review of the Literature from 1985 to 2000. Human \& Experimental Toxicology, 20, 439-451. https://doi.org/10.1191/096032701682693062

[40] Petrilli, F., Rossi, G., Camoirano, A., Romano, M., Serra, D., Bennicelli, C., et al. (1986) Metabolic Reduction of Chromium by Alveolar Macrophages and Its Relationships to Cigarette Smoke. Journal of Clinical Investigation, 77, 1917. https://doi.org/10.1172/JCI112520

[41] Aydın, Y.A. and Aksoy, N.D. (2009) Adsorption of Chromium on Chitosan: Optimization, Kinetics and Thermodynamics. Chemical Engineering Journal, 151, 188-194. https://doi.org/10.1016/j.cej.2009.02.010

[42] Wang, S.-L., Lin, T.-Y., Yen, Y.-H., Liao, H.-F. and Chen, Y.-J. (2006) Bioconversion of Shellfish Chitin Wastes for the Production of Bacillus subtilis W-118 Chitinase. Carbohydrate Research, 341, 2507-2515. https://doi.org/10.1016/j.carres.2006.06.027

[43] Kumar, M.N.R. (2000) A Review of Chitin and Chitosan Applications. Reactive and Functional Polymers, 46, 1-27. https://doi.org/10.1016/S1381-5148(00)00038-9 
[44] Dutta, P.K., Dutta, J. and Tripathi, V. (2004) Chitin and Chitosan: Chemistry, Properties and Applications. Journal of Scientific \& Industrial Research, 63, 20-31.

[45] Tharanathan, R.N. and Kittur, F.S. (2003) Chitin-The Undisputed Biomolecule of Great Potential. Critical Reviews in Food Science and Nutrition, 43, 61-87. https://doi.org/10.1080/10408690390826455

[46] Babel, S. and Kurniawan, T.A. (2003) Low-Cost Adsorbents for Heavy Metals Uptake from Contaminated Water: A Review. Journal of Hazardous Materials, 97, 219-243. https://doi.org/10.1016/S0304-3894(02)00263-7

[47] No, H.K. and Meyers, S.P. (1995) Preparation and Characterization of Chitin and Chitosan-A Review. Journal of Aquatic Food Product Technology, 4, 27-52. https://doi.org/10.1300/J030v04n02_03

[48] Guibal, E. (2004) Interactions of Metal Ions with Chitosan-Based Sorbents: A Review. Separation and Purification Technology, 38, 43-74. https://doi.org/10.1016/j.seppur.2003.10.004

[49] Maruca, R., Suder, B.J. and Wightman, J. (1982) Interaction of Heavy Metals with Chitin and Chitosan. III. Chromium. Journal of Applied Polymer Science, 27, 4827-4837. https://doi.org/10.1002/app.1982.070271227

[50] Krajewska, B. (2004) Application of Chitin- and Chitosan-Based Materials for Enzyme Immobilizations: A Review. Enzyme and Microbial Technology, 35, 126-139. https://doi.org/10.1016/j.enzmictec.2003.12.013

[51] Chivrac, F., Pollet, E. and Averous, L. (2009) Progress in Nano-Biocomposites Based on Polysaccharides and Nanoclays. Materials Science and Engineering: $R$ : Reports, 67, 1-17. https://doi.org/10.1016/j.mser.2009.09.002

[52] Seo, S.-W. (2006) Depolymerization and Decolorization of Chitosan by Ozone Treatment. Faculty of the Louisiana State University and Agricultural and Mechanical College in Partial Fulfillment of the Requirements for the Degree of Master of Science in the Department of Food Science, Chung-Ang University.

[53] Mima, S., Miya, M., Iwamoto, R. and Yoshikawa, S. (1983) Highly Deacetylated Chitosan and Its Properties. Journal of Applied Polymer Science, 28, 1909-1917. https://doi.org/10.1002/app.1983.070280607

[54] Synowiecki, J. and Al-Khateeb, N.A. (2003) Production, Properties, and Some New Applications of Chitin and Its Derivatives. Critical Reviews in Food Science and Nutrition, 43, 145-171. https://doi.org/10.1080/10408690390826473

[55] Huei, C.R. and Hwa, H.-D. (1996) Effect of Molecular Weight of Chitosan with the Same Degree of Deacetylation on the Thermal, Mechanical, and Permeability Properties of the Prepared Membrane. Carbohydrate Polymers, 29, 353-358. https://doi.org/10.1016/S0144-8617(96)00007-0

[56] Mohapatra, D., Mishra, S. and Sutar, N. (2010) Banana and Its By-Product Utilisation: An Overview.

[57] Wobiwo, F.A., Alleluya, V.K., Emaga, T.H., Boda, M., Fokou, E., Gillet, S., et al. (2017) Recovery of Fibers and Biomethane from Banana Peduncles Biomass through Anaerobic Digestion. Energy for Sustainable Development, 37, 60-65. https://doi.org/10.1016/j.esd.2017.01.005

[58] Alavudeen, A., Rajini, N., Karthikeyan, S., Thiruchitrambalam, M. and Venkateshwaren, N. (2015) Mechanical Properties of Banana/Kenaf Fiber-Reinforced Hybrid Polyester Composites: Effect of Woven Fabric and Random Orientation. Materials \& Design (1980-2015), 66, 246-257. https://doi.org/10.1016/j.matdes.2014.10.067

[59] Joseph, S., Oommen, Z. and Thomas, S. (2006) Environmental Durability of Bana- 
na-Fiber-Reinforced Phenol Formaldehyde Composites. Journal of Applied Polymer Science, 100, 2521-2531. https://doi.org/10.1002/app.23680

[60] Srinivasababu, N., Rao, K.M.M. and Kumar, J.S. (2009) Experimental Determination of Tensile Properties of Okra, Sisal and Banana Fiber Reinforced Polyester Composites. Indian Journal of Science and Technology, 2, 35-38.

[61] Rahman, M.M., Islam, T., Nayeem, J. and Jahan, M. (2014) Variation of Chemical and Morphological Properties of Different Parts of Banana Plant (Musa paradisica) and Their Effects on Pulping. International Journal of Lignocellulosic Products, 1 , 93-103.

[62] Cherian, B.M., Pothan, L.A., Nguyen-Chung, T., Mennig, G., Kottaisamy, M. and Thomas, S. (2008) A Novel Method for the Synthesis of Cellulose Nanofibril Whiskers from Banana Fibers and Characterization. Journal of Agricultural and Food Chemistry, 56, 5617-5627. https://doi.org/10.1021/jf8003674

[63] Elanthikkal, S., Gopalakrishnapanicker, U., Varghese, S. and Guthrie, J.T. (2010) Cellulose Microfibres Produced from Banana Plant Wastes: Isolation and Characterization. Carbohydrate Polymers, 80, 852-859. https://doi.org/10.1016/j.carbpol.2009.12.043

[64] Ortega, Z., Morón, M., Monzón, M., Badalló, P. and Paz, R. (2016) Production of Banana Fiber Yarns for Technical Textile Reinforced Composites. Materials, 9, 370. https://doi.org/10.3390/ma9050370

[65] Heatubun, C.D., Dransfield, J., Flynn, T., Tjitrosoedirdjo, S.S., Mogea, J.P. and Baker, W.J. (2012) A Monograph of the Betel Nut Palms (Areca: Arecaceae) of East Malesia. Botanical Journal of the Linnean Society, 168, 147-173. https://doi.org/10.1111/j.1095-8339.2011.01199.x

[66] Srinivasa, C. and Bharath, K. (2011) Impact and Hardness Properties of Areca Fiber-Epoxy Reinforced Composites. Journal of Materials and Environmental Science, 2, $351 \mathrm{e} 6$.

[67] Venkateshappa, S.C., Jayadevappa, S.Y. and Puttiah, P.K.W. (2012) Mechanical Behavior of Areca Fiber Reinforced Epoxy Composites. Advances in Polymer Technology, 31, 319-330. https://doi.org/10.1002/adv.20255

[68] Muxel, A.A., Gimenez, S.M.N., de Souza Almeida, F.A., da Silva Alfaya, R.V. and da Silva Alfaya, A.A. (2011) Cotton Fiber/ZrO 2 , a New Material for Adsorption of Cr(VI) Ions in Water. CLEAN Soil, Air, Water, 39, 289-295. https://doi.org/10.1002/clen.201000165

[69] Qu, R., Sun, C., Ma, F., Zhang, Y., Ji, C., Xu, Q., et al. (2009) Removal and Recovery of $\mathrm{Hg}$ (II) from Aqueous Solution Using Chitosan-Coated Cotton Fibers. Journal of Hazardous Materials, 167, 717-727. https://doi.org/10.1016/j.jhazmat.2009.01.043

[70] Skjåk-Bræk, G., Anthonsen, T. and Sandford, P. (1989) Chitin and Chitosan. Elsevier Applied Science, London.

[71] Udaybhaskar, P., Iyengar, L. and Rao, A.P. (1990) Hexavalent Chromium Interaction with Chitosan. Journal of Applied Polymer Science, 39, 739-747.

https://doi.org/10.1002/app.1990.070390322 